\title{
Market Responses to Global Governance: International Climate Cooperation and Europe's Carbon Trading
}

\author{
Federica Genovese
}

January 3, 2020*

\begin{abstract}
International environmental cooperation can impose significant costs on private firms. Yet, in recent years some companies have been supportive of international climate agreements. This suggests that under certain conditions environmental accords can be profitable. In this paper I seek to explain this puzzle by focusing on the interaction between domestic regulation and decisions at international climate negotiations. I argue that global climate cooperation hurts the profits of polluting firms if domestic governments do not shield them from international compliance costs. Vice versa, if firms are subject to protective (i.e. insufficiently severe) instruments at home, firms can materially gain from international climate agreements that sustain expectations about their profitability. I test the argument with an event study of the effect of decisions at the UN Framework Convention on Climate Change (UNFCCC) on major European firms that received free carbon permits in the early stages of the European Union Emission Trading Scheme (EU ETS). The analysis suggests that financial markets carefully follow the international climate negotiations, and reward the regulated firms based on the outcome of UNFCCC decisions. The evidence indicates the advantageous interplay between certain types of domestic regulations and international regimes for business. It also shows the perils of privately supported policy for the effectiveness of international public good provision.
\end{abstract}

Keywords: businesses; climate change; market regulation; global governance; international negotiations

*University of Essex, fgenov@essex.ac.uk. I thank Patrick Bayer, Thomas Bernauer, Jeff Colgan, Jessica Green, Alexandru Grigorescu, Katja Michaelowa, Stefan Renckens, Christina Schneider, Detlef Sprinz, Matt Winters and two anonymous reviewers for constructive comments. I also thank Thibaud Henin and Georg Zachmann for advise on the EU firms' data, Endre Tvinnereim for help with the survey data, and Winifred Michael for great research assistance. Previous versions of this paper were presented at ISA 2014, PEIO 2015, MPSA 2015, SPSA 2016 and Virtual IPES 2017 meetings. 
A long-standing topic of debate in political economy is how international regulatory agreements affect private companies. Classical views maintain that national interests prevent states from credibly committing to global cooperation. Yet, recent research has raised the possibility that international cooperation has real market repercussions. Accordingly, multilateral agreements have significant distributive consequences, provide crucial information on firms' economic outlooks, and materially affect the financial performance of targeted firms (Bechtel and Sattler, 2015; Wilf, 2016).

This paper explores how interactions between domestic systems and international regulatory cooperation directly influence private profits in the area of climate policy. In climate politics research, the increasing consensus is that, despite the costly actions domestic compliers face to mitigate their emissions, the effects of international climate agreements on private profits can vary significantly (Bernhagen, 2008, Meckling, 2011; Bulkeley et al., 2014). While cooperation may hurt the financial gains of some companies, it may generate positive returns for others. However, the open question is what determines these distributive material consequences of international climate policy. It is increasingly clear that some firms have more advantages than others in absorbing (or overcoming) the costs of climate regulation. But what are the conditions in which private companies - and especially polluting companies usually expected to lose from climate regulation - profit from global climate agreements?

In the attempt to answer this question, some studies point to the heterogeneity of firms with different market attributes. According to recent research, some companies profit from markets generated by international climate regulation because they are willing to invest in innovation, and therefore they align with global environmental policy frameworks Kim et al. 2016; Keohane and Victor, 2016). Other works however indicate that investors reward firms that become entrepreneurial about climate change action as the international bodies in charge seem particularly weak (Hale, 2016). Along these lines, I maintain that a most crucial condition is the pre-existing domestic policy context in which firms operate. National policy design is often an understated attribute of the private sector's reactions to international environmental cooperation (Green, 2013). Yet, in some cases domestic policy may protect firms from international regulation, and this may consequently influence investors' expectations about firms' profits.

The premise of my argument is, thus, that the regulations implemented within the boundaries of a country (or a set of countries) can create advantages for the absorption - and, thus, 
exploitation - of international climate agreements. Specifically, I maintain that decisions at the United Nations Framework Convention on Climate Change (UNFCCC) that are relevant to firms subject to domestic climate regulations affect investors' expectations about the profitability of these firms. This is because lax domestic climate policy can in some cases offer opportunities for firms to circumvent material costs while still de facto complying with international regulations. For example, UNFCCC decisions on the interlinkage of carbon emission markets may affect private firms in domestic contexts where non-stringent climate policy is in place. Investors of firms with stakes in carbon regulation through these markets should carefully follow UNFCCC deliberations on carbon market agreements, and buy stocks according to how the multilateral decisions affect domestically regulated firms. If firms are purposefully protected from mitigation costs that may accrue from international accords (e.g. with domestic subsidies), the regulated companies would enjoy 'broader' international climate cooperation, because this gives them more benefits - such as access to cheap market-based instruments for abatement. I then expect that the returns of regulated firms are positive if a new climate agreement strengthens the international supply of cheap mitigation linked to lax domestic regulation.

To test the proposed argument, I examine the financial repercussions of UNFCCC agreements on a number of major European firms between 2005 and 2010. I select large European firms because these are regulated by the European Union Emission Trading Scheme (EU ETS), the largest mandatory market for pollution permits in the world. I also choose these years to test my proposition because in this period, and especially in the early years (2005-07), the EU ETS was by definition a lax domestic regulation. ${ }^{1}$ Crucially, the EU ETS was set up with two important institutional features. Firstly, during this period - and especially in the 2005-07 years - the allowances envisioned by the EU ETS were given to the regulated polluting firms for free to avoid firms' relocation..$^{2}$ Secondly, while the EU cap-and-trade was envisioned as a legislatively independent market, in these years it was linked to international offset projects deployed in developing countries. By performing mitigation throughout these projects, the European firms could acquire cheaper credits while simultaneously 'banking' the more expen-

\footnotetext{
${ }^{1}$ After 2010, a new regulatory phase of the EU ETS coincided with macroeconomic events such as the beginning of the Eurocrisis and the end of the commodity 'supercycle'. For more on the impact of the crisis on EU ETS firms' trading behavior, see Bayer (2019).

${ }^{2}$ During the first period (2005-07), also called the 'earning by doing' phase, all permits were allocated for free. The second period (2008-12) set the rules for future allocation, whereas the third period (2013-2020) has seen a turn to auctioning an amount of permits.
} 
sive European allowances at home. Importantly, the UNFCCC could decide on the procedures ruling the international offset credits. In light of these attributes, the EU ETS firms should have been shielded from any cost of global climate cooperation, because they were involved in mitigation action at virtually zero expenses. $3^{3}$ In other words - and in contrast to theories of compliance burden, the regulated EU firms would have experienced positive returns following UNFCCC agreements that guaranteed the continuous access to low-cost international permits.

Results from an event study analysis of firms' yields during the annual UNFCCC negotiations suggest that international agreements indeed affected the returns of the European firms covered by the EU ETS, as the theory suggests. International climate decisions associated with a sustained flow of cheap carbon permits for EU regulated companies were received as 'good news' from investors, and triggered a significantly positive shot-term profit for the EU ETS firms. This finding corroborates other qualitative research on the EU carbon policy (Victor and House, 2004; Newell and Paterson, 2010, Green, 2017) and is in line with the general belief that governments can complement international political commitments and domestic economic advantages (Keohane, 1984). But the paper also goes a step further. The results indicate that firms can profit not only from how international regulation overlaps with domestic regulation, but also from how relevant multilateral announcements at international negotiations sustain the long-run credibility of such domestic regulation. While little research has so far looked at transnational alliances of firms and self-regulatory efforts in the context of global climate policy, this paper suggests that international relations scholars working on climate change should more carefully look at how firms gain benefits and costs from international regulatory arrangements and then, in turn, how those might affect the behavior of firms.

\section{The Argument}

International climate change agreements seek to guarantee the stability of the global climate at the cost of private adjustments. The burden of complying with the regulations of international climate agreements often leads firms to lobby against meaningful cooperation. At the same time, not all states experience the same type of lobbying and not all firms have contrasted climate cooperation in the same way. Several global firms supported the 1992 UN Climate Convention, and many business associations pushed for strong climate institutions at the 2015

\footnotetext{
${ }^{3}$ Several studies suggest that the over-supply of free emission allowances in Phase I was systematically cashed in, resulting in a significant windfall gain. See Bovenberg and Goulder (2001).
} 
Paris negotiations. $4^{4}$

An explanation for why firms may not oppose environmental action (among other examples of public good provision) is that international regulation may support the arrangements of firms in states with favorable domestic regulation. In the case of global climate cooperation, firms' response to global climate policy may vary with the level of domestic policy in the places where they operate, and thus where they are liable for compliance. In regions where domestic policy enforces less reliance on polluting resources and more adoption of energy efficient production, firms may anticipate high levels of adjustment costs to global climate agreements. After all, credible international agreements require countries with low regulation to increase their regulatory levels, while countries with higher regulatory stringency at the time of the agreement experience lower adjustment costs (Simmons, 2001). So, if the domestic climate regulation context generates costs for domestic firms, then an international agreement that makes regulation more stringent adds burden to those costs.

Vice versa, in places where firms experience lax environmental regulation - be it, for example, because they were involved in the making of domestic green policy - adjusting to international regulation may be less costly. In fact, in the latter circumstances there may be international mechanisms that may be even profitable for these firms. This is precisely what I argue in the rest of the paper below. Noticeably, my argument inverts the so-called trading up logic (Vogel, 1995), according to which firms that already comply with strict environmental regulation due to strong regulation at home profit from international regulation because this levels their uneven playing field. In this paper, I argue that firms due to too lax environmental regulation can profit materially from international regulation.

\section{Winning from Climate Regulation: Firms and Carbon Pricing}

In order to discuss the implications of lax carbon regulations for trading firms, one should first ask what form climate regulation usually takes. Here I focus on market-based climate change regulation. This is often assumed to have deep implications on firms' mitigation behavior because, by placing a price on carbon emissions, it seeks to change the economic incentive structure of polluting (Bovenberg and Goulder, 2001). One most common form of market-

\footnotetext{
${ }^{4}$ The Guardian. 2015. 'More Big Businesses Push For Stricter Environmental Regulations.' 4 February.
} 
based climate regulation is emissions trading (also called cap-and-trade). 5

The reason why emissions trading has become the strategy of choice of many governments in recent years is its less intrusive character vis-à-vis a carbon tax. Compared to a plain carbon tax, in an emissions trading scheme (ETS) regulators circulate allowances at a set price. If the price of carbon allowances is high and does not meet ex ante net sales, then firms have to either abate emissions or buy the required allowances. Consequently, regulated firms face an increase in production costs compared to non-regulated firms, and may experience a drop in returns from investors concerned with their profits. However, if the per-unit carbon price is sufficiently manageable and the quantity of allowances equal net sales, then firms have no significant negative effects from this carbon regulation. They may even strike a profit from cheap carbon permits if investors believe in their capacity of trading their free allowances or cheaply adopting new technology. ${ }^{6}$

The magnitude of the revenue produced by the ETS fundamentally depends on how many permits the firm owns (Baldwin, 2008; Bayer, 2019). A 'strict' ETS that provides small amounts of allowances to meet a high cap generates high burdens on complying firms (Hepburn et al. 2006). Vice versa, a 'soft' ETS that provides large amounts of cheap allowances protects private profits while stimulating firms' technological innovation and de facto subsidizing production. Clearly, a soft policy that distributes a number of free allowances equivalent to firms' future emissions offsets its intrinsic regulatory burden, because firms can clean up for free or otherwise sell permits that were costless to begin.7 Following this logic, firms around the world should have a strong preference for a soft ETS (Genovese and Tvinnereim, 2019).

Along these lines, history indicates that polluting firms in the most industrialized democracies have often formed well-organized groups to shape regulations and, as far as emissions trading is concerned, industrial have repeatedly obtained free permit allocation. This is the case of the cap-and-trade system discussed in 2008 in Australia, or the sulfur market implemented in the 1990s in the United States. Similarly, the ETS debate in Europe in the 2000s

\footnotetext{
${ }^{5}$ I focus on market-based approaches also because my unit of interest is the firm, and carbon pricing has the largest structural effects on firms' acceptance of energy and environmental transformation.

${ }^{6}$ See Appendix for a simple formal illustration of the relation between carbon price and firms' profit in an emissions trading scheme.

${ }^{7}$ Furthermore, free allocation of pollution allowances puts regulated firms in an advantageous international commerce position, because it can harshen rivals' terms of competition and increases the value of the allowances owned by regulated firms (Grubb and Neuhoff, 2006). Investors would expect the regulated firms to improve terms of production while adjusting to emissions abatement practices at low cost. As Bovenberg and Goulder (2001) show, only a relatively small allocation of emissions allowances is necessary to compensate industries for changes in profits due to carbon costs. Hence, revenue can easily increase for firms under a lax ETS.
} 
was also skewed by powerful industrial lobbies (Martin et al., 2015). The EU regulators wanted a system that would cover the European emitters in polluting sectors such as power and manufacturing while minimizing their potential loss of competitiveness (especially among exporters). Firms were open to a system of compensation in return to abstain from moving production and investment to areas with laxer climate regulations. Ultimately, the set-up of the EU ETS was negotiated so that initially the regulated firms would have been considered in training, hence receiving a large number of free carbon allowances. Following a certain period (namely, from the third EU ETS 'phase' starting in 2013), the cap was meant to be raised so to make the price of allowances more competitive, and the policy more efficient.

These dynamics point to the established fact that a cap-and-trade regulation involving cheap permit allocation creates a set of domestic winners that can profit from price variation of allowances (Bushnell et al., 2013). What is ignored, however, is whether these winners can also profit from international agreements that affect the ETS mechanism. In the following section, I explore precisely the link between UNFCCC decisions and the EU ETS regulation, and how the feedback between the two may have made the profitable features of a lax climate regulation even more toothless. I focus on the mechanism for which UNFCCC accords on international 'offsetting' projects can strengthen how cheaply European firms can fulfill climate regulation 8 More specifically, I explicate how the market value of EU regulated firms may have increased in the aftermath of UNFCCC announcements that strengthened the link between the 'soft' EU ETS and cheap international pollution permits.

\section{UNFCCC Meetings and the European Emission Trading Scheme}

This paper claims that international climate agreements can cause significant variation in investments on polluting firms subject to protective environmental regulations at home. In this section I further contextualize the argument by describing how UNFCCC deliberations can affect the profits of the European ETS regulated firms scrutinized in this paper.

The UNFCCC was established at the 1992 Rio Earth Summit and is currently the main

\footnotetext{
${ }^{8}$ Surely international climate agreements that expand the accessibility to project-based compliance credits would also reduce the value of EU allowances. This would then make over-allocated permits less profitable. At the same time, an increase in credit-providing projects in the developing world lowers the price of the international credits, so strengthening project-management emissions abatement within the EU ETS means that EU-based companies have a stronger incentive to buy credits abroad and cash in the remaining European allowances rather than cutting emissions at home.
} 
international organization involved in global GHG abatement. The Convention coordinates quantified reduction targets and seeks to harmonize national regulations for mitigation and adaptation, including the fungibility and security of global emission allowances. Intergovernmental meetings occur twice a year and last roughly two weeks. I focus here mainly on the winter meetings. These correspond to the yearly Conference of the Parties (COPs), which are the main deliberators of the UNFCCC 9

Decision-making is based on consensus voting over a long list of issues discussed in the course of the annual meetings. Informally, some parties may have more influence on some issues than on others. For example, countries such as the European Union member states 'own' some agenda points, and may dictate the multilateral decisions on their salient issues. That said, research indicates that international agreements do not always reflect the interests of the most powerful states. In fact, developing countries have been frequently successful at tilting mitigation policy decisions or linking their policy demands to carbon market strategies (Betzold, 2010). On the issue of emission trading and carbon pricing in particular, decision-making at the UNFCCC has been historically characterized by a certain amount of uncertainty. And even if there was reason to believe that UNFCCC negotiations and positions are endogenously predetermined, the timing of the decisions would not be obvious at the outset of the negotiations, so any short-run movement of stock market values in regulated firms may still be causally driven by information about EU ETS profitability emerging from the international talks.

As part of the Kyoto Protocol flexible mechanisms, emission trading is a fundamental agenda point at each annual COP. The UNFCCC can deliberate on 'guiding principles' such as the terms in which emissions market can be monitored and in which permits can be deemed reliable. Evidently, these types of decisions do not have any legal repercussion for compliers. Rather, they release information that regulators such as the European Commission can integrate in their approach to regulate emissions permits. Hence, if the UNFCCC collectively decided, for example, to continue distributing allowances in the present instead of enforcing a portioning of current allowances for the future, this would imply less pressure on EU governments to restrict the present provision of carbon allowances 10

\footnotetext{
${ }^{9}$ The other yearly UNFCCC meeting occurs in Bonn in the spring/summer. These gatherings are rather technical and do not involve the presence or deliberation of heads of state.

${ }^{10}$ Vice versa, if the UNFCCC agreed on collectively pursuing more stringent policy lines - e.g., restricting commitment period reserves - then EU regulators would be pressed to allocate fewer free permits. But these decisions would only affect domestic policy-makers' perceptions of carbon trading, and only indirectly influence investors' assessment of regulated firms. For example, at the 2008 Poznan COP governments agreed on "financial
} 
I concentrate here on the more direct way in which the UNFCCC can materially influence private returns. This involves decisions over the terms in which international abatement projects (also called 'offset' projects) can feed in regional carbon markets. While the UNFCCC has no say on the domestic setup of carbon markets such as the EU ETS, it can set the quantity of carbon permits circulated via the Clean Development Mechanism (CDM) and the Joint Implementation (JI). These are project-based programmes led in developing countries linked to carbon markets and de facto accepted by most ETS regulators around the world. Each tonne of CO2 equivalent reduced through a CDM and a JI project generates, respectively, a Certified Emission Reduction (CER) and an Emission Reduction Unit (ERU).

In the case of the EU ETS, although the European Emission Allowances (EUAs) are the only cashable units within the European scheme, firms are allowed to use CERs and ERUs to surrender for compliance obligations ${ }^{11}$ Initially the EU Commission welcomed the linkage between the domestic carbon market and CDM/JI as a way to enhance technology transfer while stimulating a global market for carbon - one of the essential goals of the 1997 Kyoto Protocol. ${ }^{12}$ Starting with a discussion of the problems of CDM/JI monitoring and verification in 2008 and then with formal reforms to the acceptance of ERUs/CERs in 2012, the circulation of offset credits in the EU ETS progressively became more restrictive. So, while today these credits still circulate in several UNFCCC-complying carbon markets, the linkage between the CDM/JI credits and the EU ETS mattered especially in the early pre-2008 stages, before the EU on its own began to restrict use of CDM and JI, and energy prices peaked following the commodity 'supercycle'.

Notably, by affecting the global supply of the CDM- and JI-generated credits, the UNFCCC can influence the amount of credits available to compliers in carbon markets. So, with regards to the EU ETS in the pre-2008 years, UNFCCC decisions related to international

support" for emissions trading and new "quota" to be traded for other industries, as per a UNFCCC Press Release of December 12, 2008. Five days later, on December 17, the EU announced its 20-20-20 targets that extended the allocation of emissions permits to more vulnerable economic sectors. The markets seemed to favor this chain of decisions, because of the sustained interest in supporting cheap emissions abatement.

${ }^{11}$ CERs and ERUs can be acquired to meet quantitative emission reduction commitments under the Kyoto Protocol. Thus, they can be bought by 'compliance buyers', which are entities seeking to purchase offsets to comply with a regional scheme, or 'sovereign buyers', which are virtually all industrialized 'Annex I' countries with commitments under the Kyoto Protocol. After 2012 changes were made to the type or CERs/ERUs usable in the EU ETS, although they can still be used if sourced from a least developed country.

${ }^{12}$ Differently from credits from other sources (e.g. Russia), the link between the EU ETS and especially the CDM projects was also based on principles of global fairness that made credit acceptance particularly compelling. 
offset credits affected how EU ETS firms could abate emissions at the lowest possible cost. Specifically, UNFCCC outcomes that increased the international supply of CERs and ERUs for carbon market participants would have altered the compliance costs of EU ETS regulated firms, because the costs of international credits have always been substantially lower than the EU ETS allowance price ${ }^{13}$ Thus, the opportunity to 'clean up' through CDM and JI projects should have created incentives for EU ETS regulated firms to venture in developing countries and perform easy mitigation tasks in order to cheaply obtain more permits. At least until the reforms tackled in 2008 (which coincided with the collapse of some Western economies and other UNFCCC decisions), it was rational for the European firms to use the converted allowances for compliance and sell the excess freely allocated allowances to competitors, or bank them to avoid the cost of more stringent compliance in later years.

It is worth noting that high supplies of CERs and ERUs would also put pressure on the absolute value of the original EU ETS carbon allowances, which could also lead to a mixed effect of UNFCCC decisions on offset credits. This is because firms in foreign countries e.g., Australia and Japan - also have had access to the credits allocated via the CDM and JI projects. Consequently, more international credits could in principle benefit a large range of global firms and thus reduce the benefits of free emissions allowances for EU ETS regulated compliers. Still, in the years between 2005 and 2012 large countries like the United States did not engage with CERs and ERUs. In fact, in these years it was precisely European firms with free carbon allowances that went decisively after international offset credits, possibly to clear the market of these cheap opportunities ${ }^{14}$

This discussion leads me to expect that, for the early years of the lax EU ETS regulation, international climate agreements that widened the scope of cheap abatement for the European regulated firms increased their short-term profitability. I test this proposition in the empirical section of this paper. To be clear, this hypothesis should hold only if I assume that the UNFCCC is capable of revealing new information on the future of carbon trading that would not otherwise be known to investors beforehand. In other words, the EU ETS should be 'informationally efficient,' which means that the firms' share prices reflect all publicly available

\footnotetext{
${ }^{13}$ Some studies indicate that between 2005 and 2010 the price of 'primary' CERs (which are CERs earned by project originators through the CDM) has been almost nil (Victor, 2011, p. 78-79).

${ }^{14}$ The main receivers of emissions permits in the EU ETS were precisely the bigger multinationals, which seem to have exploited their global chains to engage with CDM projects and benefits from CERs (Koch et al. 2014).
} 
information. So, while EU ETS investors may know the preferences of the EU delegation or their national representatives, the final outcome established at the UNFCCC negotiations is unknown before its release. This is plausible because, even when the precise agenda of the meetings is decided beforehand, investors cannot anticipate with precision the final timing and shape of decisions in the final stage of the negotiations. Consequently, if the outcomes of the UNFCCC negotiations cause 'abnormal' returns - that is, returns that cannot be explained by regular movements of financial assets - in the books of carbon trading firms at the times of COP meetings, this should be because information from the UNFCCC conferences shapes the expectations that investors have for EU ETS firms.

\section{Empirical Investigation}

\section{Sample and Firms' Measurements}

To investigate the link between outcomes at the UNFCCC climate meetings and financial profits of loosely regulated companies, I concentrate on the daily stock performance of 38 randomly selected publicly-traded companies of the EU ETS. The firms were drawn based on specific criteria. My study is focused on the years before the deepening of the European financial crisis, which inevitably changed the fundamentals of the market performance of all firms around Europe (Koch et al., 2014). This period coincides with the early phases of the EU ETS when pollution allowances were given for free. More prominently, I focus on European firms trading between 2005-2007, the years of the laxest phase of the EU ETS (Phase I). I use the years 2008-2012 (Phase II) as comparison units.15

Of the firms involved in EU ETS in Phase I and II, I discarded the firms with small emitting facilities ( $<5$ installations) and those that stopped existing or were created in the course of the years under analysis. I also ignored those that do not trade in international stock markets, and only considered the firms that are listed on international platforms - namely the SP500 and STOXX600. Following Bushnell et al. (2013), I identify 260 companies that at the time had the majority of sales earned in Europe, so that are fully exposed to the EU ETS regulation. Of these, 114 have non-zero allowance data in the EU's Community Independent Transaction Log, and are therefore of interest for my analysis of 'protected' (i.e. loosely regulated) EU ETS firms. I then randomly sampled one third of them (38) for the central analysis, i.e. the

\footnotetext{
${ }^{15}$ More than 2000 firms traded in Phase I, while more than 3000 firms were listed in Phase II.
} 
investigation the effect of international climate agreements on domestically regulated firms in the EU. ${ }^{16}$ In separate analyses, I match these $38 \mathrm{EU}$ firms to their most-similar non-EU firms. These additional data allows for an alternate comparison with firms at the time not regulated by emission trading schemes, hence not subject to any beneficial domestic carbon policy.

In the period under consideration the EU ETS firms under investigation were among the 500 largest global companies, for which the annual value of reached permits reached nearly $\$ 60$ billion. The firms are representative of the nature of the EU ETS, as shown by the breakdown by country and sectors of production in Figure 1. The sample spreads across the twelve founding EU member states. Several companies have headquarters in London; this makes the United Kingdom the 'home' of roughly one third of the observed firms, followed by Germany in terms of represented companies. The comparison between the relative numbers of firms in the sample and in reality indicates that the sample under-represents firms based in Ireland and Spain and over-represents France, but it is otherwise representative of the other major countries. Across sectors, electricity generation and manufacture are the two largest ISIC industries depicted in the sample. The sectoral break-down is reflective of the real-world EU ETS, where power generation and manufacturing correspond to more than 85 percent of the regulated GHG emissions.

I collected the firms' stock prices in current US dollars for the period between April 2005, when the EU ETS was first launched, to December 2010, when the Great Recession in Europe inevitably clouded the relation between financial private returns and any international deliberation, let alone the UNFCCC meetings. ${ }^{17}$ The stock prices were collected through Thomson Reuters Datastream and are equivalent to the Dow Jones STOXX 600 market index (Bushnell et al., 2013). The first period includes the years between April 2005 and May 2007, which corresponds to the first phase of operation of the EU ETS. The second period corresponds to June 2007 to December 2010. The first phase was by far the more volatile, while the second phase included years of internal negotiations in view of the 2013 reforms. As per my theoretical discussion, I expect my theory to be most pertinent to the 2005-07 years, because of the mix of lax domestic regulations in combination with uncertainty around cooperation for carbon

\footnotetext{
${ }^{16}$ See the names of the selected EU ETS-regulated companies in Table A.1 in the Appendix.

${ }^{17}$ Current USD are the equity values reported in financial databases, and are often used in other event study analyses such as Bechtel and Schneider (2010) and Gaikwad (2013). Of course, current prices are influenced by the effect of price inflation, but they work well for the purpose of event study analyses because the anticipated profitability changes assumed by the so-called efficient financial market hypothesis should be the immediately reflected in current prices.
} 
trading international mechanisms.

Figure 2 provides the basic context of the EU ETS trends between 2005 and 2010. The figure shows that in 2005-07 allowance prices stayed above the threshold of 10 Euro per carbon ton, a price level that suggests that at this stage investors were taking the policy seriously and collecting information about the implications of carbon permits. Importantly, in 200507 delegates at international climate meetings were still extensively discussing the set up of carbon trading and the linkage with other market instruments. According to Gupta (2010, p. 646), during this phase "the EU had to renew its efforts to convince other countries to ratify the Kyoto Protocol and push implementation efforts further." As such, this is a period when international cooperation could really make a difference for the future of carbon regulation. It is worth noticing that prices seemed to react to some COPs. For example, while the day before the Nairobi COP a ton of carbon was valued at 15.6 Euros, the day after the conclusion of the negotiations it was almost 18 Euros. This pattern suggests some connection between COP meetings and EU ETS trends. However, in what follows I rely on stock performance measures to systematically examine the effect of international climate policies on the firms' financial value.

Stock prices show clear signs of non-stationarity (Dickey-Fuller p-value $=.3$ ), which means that the series present unit roots and cannot be used for consistent estimation. I log-difference the price to obtain continuously compounded returns. This transformation is econometrically preferable but also theoretically useful, because returns capture short-term changes, the primary unit of interest in this study. I calculate first differences to standardize the returns and make them comparable across all 38 firms. Figure 3 illustrates the aggregate average returns for the period between April 2005 and April 2007, which indicate stationarity because the series floats around zero.

The plot noticeably shows that much volatility occurred in April 2006 with the EU first disclosure of verified emissions that led to a sharp drop in carbon prices. This event is unrelated to the international negotiation activities central to this paper; rather, I am interested in the variation around the time of the COPs (see gray bars in Figure 3). My hypothesis suggests that, in case of 'good outcomes' related to the expansion of offset credits for regulated firms, the price/return of EU ETS firms should increase. Vice versa, outcomes that do not add information about the stream of cheap international permits should not cause positive returns. Similarly, 'good outcomes' would also fail to have similar positive effects on firms in countries 
where domestic carbon policy is not set up to protect their short-term interests. Anecdotally, the sub-plots related to the performance of a few diverse EU firms (bottom of Figure 3) indicate that the 2005 and 2006 COPs might have indeed triggered the expected positive market reaction. To rigorously investigate these dynamics and the ramifications of my hypothesis, I now turn to describe the set up of my regression analysis.

\section{Event Study Setup and Outcome Variables}

The most effective empirical strategy to uncover how decisions at international climate meetings drive profits among European emission trading firms is an event study research design. 18 Event studies are usually set up in two steps. First, one needs to define a firm $i$ 's expected normal return $\left(\mathrm{E}\left[R_{i t}\right]\right)$, that is, the daily return one should expect in the absence of UNFCCC decisions. The simplest assumption here is that investors in the EU ETS would not deviate from trading their favorite product unless they can profit from investing in other markets that better suit their interests. In order to estimate this type of return, I estimate the following linear relationship:

$$
\mathrm{E}\left[R_{i t}\right]=\alpha_{i}+\sum_{z=1}^{Z} \beta_{i} R_{z t}+\epsilon_{i t}
$$

where $\alpha$ is a constant, $\epsilon$ is the error term, $R_{i t}$ is the return to a risky alternative asset $z$ at day $t$, and the $\beta$ is the weight that reflects how changes in the return of asset $z$ translate into changes in the return $R_{i t}$, following asset pricing theory (Bechtel and Schneider, 2010). Empirically, I estimate the weight of $R_{z t}$ with a combination of three alternative returns: a global stock market index, the NYSE American Stock Exchange Index (Amex), and the Renewable Energy Industrial Index (Renixx), to control for specific types of profits relevant to the energy industry.

In a second step I estimate the European stock market reactions to the climate negotiation outcomes by calculating the returns that deviate from the normal values at the time of a UNFCCC meeting. As I describe below, I identify as 'outcomes' the UNFCCC decisions reported by official sources. Practically speaking, an abnormal return is the difference between the observed return and the 'counterfactual' control set of estimations from the normal return $\left(\mathrm{E}\left[R_{i t}\right]\right)$ conditional on the measures of risky assets $x_{t}$ mentioned for equation (1). The abnormal return $A R_{i t}$ is then computed with the simple equation:

$$
A R_{i t}=R_{i t}-\mathrm{E}\left[R_{i t} \mid x_{t}\right]
$$

\footnotetext{
${ }^{18}$ For event studies related to my analysis, see Bushnell et al. (2013); Oestreich and Tsiakas (2015).
} 
When estimating abnormal returns, one should choose a proper time window where the error term can be also estimated. The annual climate negotiations usually last fourteen days. Realistically, multilateral decisions are rarely made at the beginning of the negotiations, and relevant statements tend to be released towards the end of the UNFCCC meetings.19 I calculate abnormal returns for a window that comprehends all the official negotiation days - roughly two weeks, depending on the meeting - plus three days preceding the negotiations and three days following the negotiations, for a total of 20 days. The returns are compiled for all Conferences of the Parties (COPs), where decisions vary in terms of timing and settled terms. I come back to the coding of the substantive terms of the COP agreements below 20

Following common practices in the literature, I use the abnormal return series to construct two quantities of interest: the basic abnormal return $(A R)$, which corresponds to the daily stock return on each firm relative to the counterfactual benchmark, and the average abnormal return relative to the whole EU market at the time of each COP $(A A R){ }^{21}$ Due to the notable sectoral and structural heterogeneity between firms in the selected EU ETS sample, the more relevant quantity of interest may be the $A A R$, i.e. mean return to the sampled EU ETS firms at time $t$. Nonetheless, I use both measures for completeness, and expect both quantities of interest to be similarly associated to carbon credit-related UNFCCC outcomes.

\section{Estimation Strategy and Explanatory Variables}

In order to estimate the effect of UNFCCC decisions on firms' returns, I employ a fixed effects linear regression where the left hand side includes the two measures of abnormal returns described in the previous section. The regression models for the two outcome variables follow, respectively, the equations:

$$
\begin{aligned}
& \mathrm{AAR}_{i j t}=\alpha_{0}+\beta_{1} \text { Good UNFCCC Outcome } \\
& t
\end{aligned}
$$

where $t$ indexes time (each day under investigation), $i$ indexes each firm, and $j$ indexes each country where firm $i$ is headquartered. In the above model, $X$ are a set of (firm- and country-

\footnotetext{
${ }^{19}$ For COPs, the most crucial part is the second week, when the UN Secretary General and the Executive Secretary seek to address the most important nodes of the discussion.

${ }^{20}$ I also calculate the EU ETS firms' returns during the summer meetings that occur in Bonn. I use these meetings to make sure to also test whether in-between conferences (i.e. conference where parties do not take resolutions) yield a change in private profits.

${ }^{21}$ UNFCCC meetings take place during weekends. Following Bechtel and Schneider (2010), I shift events occurring on non-trading days to the next trading day.
} 
level) covariates, $\eta$ and $\gamma$ respectively are the estimated firm and country fixed effects, $\zeta$ capture time effects, and $u$ is the idiosyncratic error term. ${ }^{22}$ The predictor of interest is Good UNFCCC Outcome. This is an indicator that measures when the governments at the UNFCCC agree on decisions on emissions trading that would increase cheap abatement options and 'banking' opportunities for EU ETS firms. As per the theoretical discussion, I expect its coefficient $\left(\beta_{1}\right)$ to be positive and statistically significant for the early EU ETS years.

In terms of coding, the Good UNFCCC Outcome variable was constructed with a manual content analysis of official UNFCCC documents. Most crucially, I used the daily reports in the Earth Negotiation Bulletin of the International Institute for Sustainable Development (IISD), which I afterwards compared with press releases published on the UNFCCC webpage. The IISD texts are neither a reflection of strategic positions nor a public relation-type of press. They are summaries of independent observers at the UNFCCC negotiations (Castro et al., 2014). The coding of Good UNFCCC Outcome was performed for all the days within the 20 day-window identified around each UNFCCC meeting. For each of said days, the documents were qualitatively reviewed and relevant decisions were marked down.23

Following the content analysis, the Good UNFCCC Outcome variable is assigned the value of 1 to each day in which the official documents report a decision that incentivizes the use of offset credits for current commitment periods ${ }^{24}$ or that encourage firms to obtain permits generated in CDM and JI projects.25 The variable takes a value of 0 otherwise, e.g. if at any specific day the issue of tradable credits is not addressed or no particular agreement is settled. In a separate, ordinal version, Good UNFCCC Outcome also takes a value of -1 if outcomes are 'bad', e.g. if an agreement limits the availability of international credits available to compliers, including decisions of fragmenting carbon markets or constraining mitigation projects under the EU ETS. However and as discussed later, the results are not driven by the breakdown of this variable, and they are substantively robust if the variable is defined discretely.

To illustrate the coding of the variable, on November 162006 the UNFCCC Press reported:

[The Parties agree that] the carbon market has tremendous potential, and the Kyoto mechanisms require continuity after the first commitment period to continue their expansion, and [that] the demand for credits generated through the mechanisms increase in

\footnotetext{
${ }^{22}$ Several tests suggest that random effects estimation are potentially suitable, although I prefer the fixed effects for inferential purposes. The substantive results do not change if I estimate random effects.

${ }^{23} \mathrm{~A}$ research assistant and the author coded the outcomes separately. The Kripperndorff reliability statistic of their coding was above reasonable average scores $(>.5)$.

${ }^{24}$ See the decision of November 172006 in the 2006 Earth Negotiations Bulletin, 12 (318).

${ }^{25}$ See the decision of December 142007 in the 2007 Earth Negotiations Bulletin, 12 (354).
} 
future commitment periods to sustain the market value of carbon 26

In this case, the international community agreed to sustain the linkage of credits from CDM/JI and mechanisms such as the EU ETS. Thus, in the coding the day of this decision corresponds to a Good UNFCCC Outcome for EU ETS firms $(=1)$.

A detailed list of decisions captured by the Good UNFCCC Outcome variable are reported in the Appendix. ${ }^{27}$ Once again, decisions are coded at the day level, in light of the fact that some COP have more than one relevant decision and decisions can be announced at different times during the negotiations. Nevertheless, the final agreement in the last hours of negotiations is often the main output of a COP, and Table 1 reports the essential outputs for the five COPs under considerations, suggesting how these should overall affect returns for EU ETS firms. As indicated, the intergovernmental meetings in Montreal (2005) and Nairobi (2006) made the support of complying firms with additional credits a priority. Contrastingly, the following COPs were more mixed. For example, in Bali (2007) countries focused on making carbon markets more efficient, but they also agreed on letting new parties participate in CER provision. And in the 2008-10 years, while EU ETS allocations remained mostly free, EU rules of credit auctioning were discussed and the international community started tackling issues of CDM monitoring more seriously, making 'good outcomes' for EU ETS firms less frequent. In light of these considerations, I expect the positive effect of Good UNFCCC Outcome to be most prominent in EU ETS Phase I. I predict this effect to have less influence in later EU ETS years, or for firms without EU ETS permit allocation.

\section{Control Variables}

A main feature of event studies is that they generate counterfactual-like returns to which one can compare the observed returns. Consequently, my research design has the benefit of neutralizing spurious dynamics outside the framework of investigation. Nonetheless, alternative mechanisms may explain the magnitude of abnormal returns during UNFCCC meetings. Hence, I include a set of control variables $X$ in my regressions.

First, the stock value of polluting firms may vary as a function of domestic environmental

\footnotetext{
${ }^{26}$ Report of the Ad Hoc Working Group on Further Commitments for Annex I Parties under the Kyoto Protocol. Nairobi, November 2006, p. 10-11.

${ }^{27}$ Table A.2 reports the excerpts from the Earth Negotiations Bulletin that justify the coding of each of the non-zero values for the Good UNFCCC Outcome variable.
} 
policy announcements that may fall around the timing of the COP but may be unrelated to international climate negotiations. Consequently, I estimate the effect of the variable Domestic Policy, which is a dummy that takes the value of 1 when any of the EU countries represented in the sample announced a national policy related to climate change mitigation. The coding included new renewable policies, energy efficiency programs, subsidies for biofuels and transportation policies. The variable is coded 0 otherwise 28

It is also possible that democratic elections elicit information that may be relevant for the financial performance of polluting firms. For example, elections may generate uncertainty about the incumbent government and anxiety about future cabinets, which may care more or less about the environment $($ Sattler, 2013). I control for the timing of these events with the variable National Elections that takes a value of 1 for the scheduled dates of national elections in each of the EU country a firm belongs to, and 0 otherwise. Note that I also mark with 1 the two days before and after election day, to capture electoral campaign spillovers.29

Additionally, I make sure to account for the public salience of climate change issues, which may affect decision makers' decisions at the UNFCCC as well as investors' beliefs on the profitability of polluting companies. The salience of climate change may be a function of disastrous events that occur at the time of a climate negotiation, or simply by media attention that convinces the public to closely follow the international meetings. So, I include the measure Relevant Web Searches of climate change to my regression equation. This variable is an indicator that tracks internet-users' interests in international climate events. I used Google Insights (now called Google Trends) to retrieve the volume of weekly web searches for words such as "climate change negotiations", "Kyoto Protocol" and "climate politics". I restrict my search to English queries in the EU15 countries ${ }^{30}$ Additionally, I include the value of Carbon Price to make sure that changes in firms' profits are not driven by regulation-specific mechanisms that influence the price of the EU market. Because Relevant Web Searches and Carbon Price are both non-stationary, both lags and rates are included to account for levels and changes.

\footnotetext{
${ }^{28}$ The dates of these policy announcements were traced in the National Communications to the UNFCCC and in the European Environmental Agency country briefings. They include the UK Climate Change and Sustainable Energy Act (April 2006) and the German Biofuels Quota Act (July 2006).

${ }^{29}$ Returns may be also sensitive to the timing of National Allocation Plans of permits. However, since no NAP was announced within the course of UNFCCC meetings, the effects of this variable are inevitably null.

${ }^{30}$ I gathered Google Insight data in English in order to obtain comparable information across the EU countries. The series are automatically standardized for seasonality and other temporal trends.
} 


\section{Results}

I first estimate the linear models for the years of the EU ETS first phase (2005-07), when firms should have been most sensitive to UNFCCC deliberation given the domestic characteristics of the EU regulation and the general uncertainty around carbon trading. The estimates from the econometric models are presented as coefficient plots to ease the interpretation of the findings, although the complete set of coefficients are also reported in tables in the Appendix.

Figure 4 reports the coefficients of two permutations of the AAR and AR models for the initial EU ETS period, which corresponds to the phase between April 2005 and April 2007. The first model (illustrated with a triangle) corresponds to a baseline specification with only the Good UNFCCC Outcome predictor in the right-hand side in addition to the fixed effects dummies. The second model (illustrated with a circle) corresponds to a full specification that includes the fixed effects and all the control variables presented in the previous section. To start with the correlations in the AAR model, I find that positive outcomes are positively and significantly correlated with the average EU ETS abnormal returns. The point estimate suggests that strengthening the provision of carbon permits for EU ETS firms increases average profits by about 0.07 points. This is a relevant amount if one considers the market value of some of the regulated companies. As all the firms in the EU ETS were worth about 16 billion US dollars as of April 2006, a 7 percent change in returns due to positive signals from international climate negotiations resembles a change of almost a billion US dollars. The estimations of the more restricted model confirm this result. While I also find that the occurrence of national elections, the announcement of domestic climate policies and the public salience of the climate change issue affect the financial returns of polluting firms, the variable Good UNFCCC Outcome that measures announcements of stronger linkage between the EU ETS and cheap offset credits remain robust and significant, everything else constant.

The bottom of Figure 4 report the results for the second outcome variable representing daily varying returns (AR). The baseline model reveals that 'good news' from the UNFCCC is positively correlated with the day-varying returns. The uncertainty of the AR estimates is larger than the AAR models due to the larger variation in the abnormal returns data (recall that $\mathrm{AR}$ is based on firm-specific sensitivities to the baseline stock market, while AAR is an average measure across the sampled firms). Nonetheless, the magnitude of the Good UNFCCC Outcome effect is qualitatively similar to the one for average abnormal returns. The coefficient becomes 
larger and more significant by virtue of including the control variables. These results suggest that UNFCCC decisions that seek to sustain the venues of cheap compliance for regulated firms make investors optimistic about the future profits of EU ETS companies. In other words, the findings support the hypothesis that firms privately profit from international agreements if they are adjusted to an ex ante, lax policy:31

While the 2005-07 data seem to support the theoretical argument of the paper, it is important to investigate the regressions for later periods when information had been provided on the efficiency of offset projects for effective carbon training and efficient abatement. Thus, I run the regression models on the return data centered between 2008 and 2010 (the second phase of the EU ETS). Figure 5 shows the regressions, which are presented in a similar fashion to the regressions for 2005-07. I find that the neither of the two outcome variables is significantly correlated with Good UNFCCC Outcome. The estimated coefficients of the AAR models are virtually zero. The coefficients of the daily AR regressions are negative both in the unconstrained and the constrained specification models, although they are also statistically insignificant. One interpretation of the null results for the 2008-10 years is that in the second EU ETS phase firms started internalizing the future restrictions of free allowances announced for Phase 3. Moreover, in these later UNFCCC negotiations the EU started being more vocal about problems with CDM and JI implementation and monitoring, pre-announcing domestic reforms to the qualitative acceptance of international offset credits. Thus, the null finding is overall in line with the broad theoretical expectations.

This finding does not mean that the link between multilateral decisions on international offset credits and domestic regulations is outdated or irrelevant today. For example, in 2018 for the first time the South Korean Ministry for Environment allowed the use of international offset credits in the domestic carbon market. So, my theory that international deliberation on emission trading and international credits affect the profitability of firms may be relevant for South Korea and other ETS systems that are still underresearched. More generally, the null results for the 2008-2010 years imply that the impact of international agreements on the profits of targeted firms disappears the moment domestic regulation deviates from its protective nature. As domestic regulation becomes less aligned to the interest of private actors, the influence of pertinent intergovernmental decisions may become less effective.

\footnotetext{
${ }^{31}$ I also find that returns are sensitive to national elections more than any other events included in the model, and that the daily volume of Google searches has a positive and statistically significant coefficient.
} 
The results are robust to a number of modelling choices and alternative estimations. They are not sensitive to dropping the UK companies from the sample, which may be warranted given the special status of UK business regulation in the EU and previous cap-and-trade experiments fielded in the UK before the establishment of the EU ETS (see Appendix).In additionally analyses I also explored if the effects of UNFCCC decisions supporting the provision of emissions permits vary across sectors. ${ }^{32}$ The results indicate that, although firms witness positive returns when the UNFCCC is in favour of carbon credit expansion, the main profiteers are manufacturers and, to a lesser extent, mining companies. Accordingly, power firms are neither capable of credibly use opportunities for abatement abroad nor they credibly gain from emissions trading (Oestreich and Tsiakas, 2015). This is evidence that the winners of a 'generous' carbon trading system supported by international policy are the more flexible companies, e.g. manufacturers, that can feasibly relocate if domestic regulation were to become less generous. With respect to the main hypothesis of this paper, this subsample analysis further supports the conjecture that global agreements influence investors' beliefs about the advantageousness of lax regulation.33

Because 'good' outcomes mainly manifest themselves at the end of the COP time window, I also explore if the effects are indeed strongest in the last days and how long they may last. I find that the positive average abnormal return in the EU ETS sample picks up right before the end of a UNFCCC meetings, towards the last two days of a conference, and then starts dissipating after three days. But the implications of international decisions at the UNFCCC remain relevant even if they only have short-term effects: ${ }^{34}$ Furthermore, I investigate how each of the earlier COPs may have affected private returns individually. The single COP estimations show that the Nairobi decisions created the biggest return for EU ETS firms. ${ }^{35}$ This is consistent with reports that depict the Nairobi meeting as particularly supportive of emission trading in the EU, both in terms of allowing EU countries to use most of their reserve allowances for trade or cash-in and in agreeing on new mitigation projects that could generate tradable - and, thus, profitable - emission reduction credits.

More substantively, my theory puts forward the centrality of domestic regulations to ex-

\footnotetext{
${ }^{32}$ See Table A.5 in the Appendix.

${ }^{33}$ Similarly, regressions that estimate standard errors clustered on sectors show that the substantive findings are unaltered. See Table A.8 and Table A.9 in the Appendix.

${ }^{34}$ The results are virtually equivalent if I run the estimations on the AR data, with the difference that the coefficients are overall larger. See the Appendix.

${ }^{35}$ See Table A.10 in the Appendix.
} 
plain why international climate agreements have material effects on domestically regulated companies. In so doing, my argument implies that there should not be such effects for companies whose foreign homes lacked the same type of protective regulations as the 'soft' EU ETS. To test this implication of my argument, I perform an additional test by correlating the UNFCCC outcomes codified in my dataset with the private returns of a number of non-EU ETS firms in 2005-07. The Appendix lists the non-European firms that have matching market characteristics according to the 2010 version of the Forbes Global 2000 dataset 36 For my 38 EU ETS firms, I searched the non-European companies within the same sector and with the most similar market value, sales, profits and assets. I then selected two most-similar firms for each EU ETS firm, to avoid systematic up-ward or down-ward biases ${ }^{37}$ Finally, I collected the prices of the non-EU firms following the procedure for the EU firms, i.e. through the Thomson Reuters Datastream.

After generating the two forms of abnormal returns (AAR and AR) as constructed for the EU ETS, I performed the same regressions analysis presented beforehand. Figure 6 reports the coefficients. With respect to the average abnormal returns (AAR) models, I find that in both the unconstrained and constrained models the coefficient of Good Outcomes is negative and statistically significant. This result suggests that an international climate agreement that is interpreted positively by EU ETS investors causes smaller (null or, in fact, potentially negative) returns in firms outside of the EU carbon regulation zone. The results are even more negative if I consider only firms from Annex I countries. In other words, the abnormal returns are even smaller for firms from member states that are in principle part of the international regulation decided at the COPs (see Appendix). At minimum, these data from the non-EU sample indicate that the returns of the non-European firms do not react to decisions at international climate meetings like they do for EU ETS firms, in line with my theoretical expectations.

The additional evidence reinsures that my main findings are not an artifact of temporal trends and other omitted phenomena that violate the efficient market assumption upon which the logic of the event study relies. Nonetheless, one may still worry that this observational evidence only sheds a limited amount of light on the mechanism at the heart of the paper.

\footnotetext{
${ }^{36} \mathrm{I}$ used the 2010 Forbes data, but there is a significant amount of stability in the Forbes 2010 data if compared, for example, to the 2014 data.

${ }^{37}$ For example: within the 'Food Processing' industry category of the Forbes Global 2000 database, the firms matching Danone's market attributes are Mondelez International and Archer Daniels Midland, both in the US.
} 
Importantly, I have assumed that EU firms and their investors should be sensitive of the importance of UNFCCC decisions of international credit issues in order to profit from them. How can one be sure about this? Are international offset credits more supported among EU ETS firms than unregulated firms without access to allowances?

To answer these questions, I resort to an exclusive dataset of firms' opinions on the EU ETS called the Carbon Market Survey. First fielded in 2007, this survey is annually conducted by Thomson Reuters Point Carbon. All firms covered by or somehow affiliated to the EU ETS regulation are invited to take part in the survey. Respondents are asked to provide information about their firms in terms of location, sector, emission levels, and access to allowance, and express their views and provide opinions on a number of items. The questionnaire asks opinions on the CDM/JI projects. On this end, the survey has included the questions ' Will $C D M / J I$ projects eliminate the need for internal abatement in the EU ETS?' (No/Yes) and 'Is CDM/JI the most cost-efficient way to reduce emissions?' (Completely Disagree to Completely Agree). Following my theory, one would expect that the EU ETS regulated firms (i.e. firms with access to EU allowances) would be more prone to support CDM/JI projects, for these protected firms should be the more enthusiastic supporters of the linkage between the EU ETS and offset credits.

Table 2 reports the results from correlating the responses to these two question items with the structural covariates of the survey firms, including the dummy EU ETS regulated, which refers to whether it has access to free allowances (yes/no). The regression results show that European firms directly regulated by the EU ETS are on average more supportive of CDM/JI links with the EU ETS than unregulated firms. This correlation is significant and robust to controlling the structural features of the responding firms, as well as using different modelling strategies (see Appendix). It is also worth noting that, despite the reforms following the second EU ETS phase, the correlation remains significant in the 2013 survey, at a time where fewer firms were allocated free permits overall. This seems to indicate that in 2013 firms still preferred international integration of carbon market mechanisms over fragmentation despite the announced reforms. More importantly, the survey data provides further confidence about the link between the regulatory advantages of the EU cap-and-trade regulation and the private use of international agreements to access further cheap 'solutions' to abatement goals while keeping up business-as-usual profits. 


\section{Conclusion}

Understanding how global public good cooperation affects private profits is a complex puzzle in international political economy research. In this paper I focused on how the private sector reacts to international deliberation on issues related to climate change regulation. While there is increasing evidence that the business community occasionally welcomes international climate agreements, it is less clear under which conditions international climate accords positively affect private interests in order to generate such support.

I argued that international climate agreements can have positive material repercussions on the books of private companies if the climate regulation at home is lax and protective. Zooming in on the UN annual climate meetings, I posited that if firms are subject to protective regulatory instruments that put them in the position to profit from abatement credits, they may financially gain from climate agreements that globally extend these mechanisms. I focused on emissions trading firms in the European Union as an example of firms regulated by a flexible domestic policy that fulfills international climate cooperation while, at least in the early years, protecting the core economic interests of the companies via the over-allocation of cheap allowances. I claimed that UNFCCC announcements related to the linkage of international offset projects and compliance schemes such as the EU ETS may have caused abnormal positive returns for regulated carbon trading firms, everything else constant. I tested my proposition with an event study of stock price behavior of 38 major EU ETS regulated firms during a number of international climate meetings. The analysis lends support to the view that financial markets carefully evaluate the UNFCCC outcomes. Specifically, I find that EU ETS investments react positively to multilateral decisions that reinforce the linkage between the EU ETS and international credits.

This finding is relevant to scholars interested in the interplay of environmental policy and private actors' behavior. While researchers have already indicated the intimate relation between international climate regulation and private profits broadly put (Vogel, 1995, Newell, 2010; Victor, 2011), this study sheds new light on the link between international negotiations and private profits, highlighting how multilateral announcements can affect the profitability of regulated firms. Evidently, the study is focused on Europe, but the findings should be of timely relevance for other countries where market-based carbon policies are gaining ground, such as Australia and California, or where organized private interests may have been more or 
less successful in lobbying beneficial policy terms, such as Canada. The study is also insightful to emerging economies that are piloting carbon trading systems, such as Mexico, South Africa and China (Biedenkopf et al., 2017).

For policy makers, the main lesson is that privately-shaped domestic regulations is likely to fulfill private interests at the cost of public good by perpetuating a streak of environmentally inefficient international outcomes that contribute to the revenue of a small group of firms. Fixing domestic regulations is possible and can help strengthening not only the integrity of domestic regulatory institutions but also the credibility of the international climate negotiation process. But of course, regulatory changes entail difficult decisions such as politically unfavorable subsidies or an economically intrusive role of the state. Policy makers need to reconcile whether and in which fashion these domestic transfers are worth fulfilling.

To the international governance literature, this study provides new insights on the relations between industrial lobbies and international regulators and the synergies of international organizations and domestic politics. By showing the contexts in which international deliberation and decisions yield material benefits to domestically regulated firms, this paper suggests conditions under which private companies may be willing to support or oppose international public policy. Specifically, the article highlighted how interests participating in domestic climate policy-making are able to extract gains from international rules that are favorable to them, but potentially worse for the public. 


\section{References}

Baldwin, R. (2008), 'Regulation Lite: The Rise of Emissions Trading', Regulation and Governance 2(2), 193-215.

Bayer, P. (2019), Strategic government enforcement and firm compliance with international regulation: Evidence from carbon regulation. Paper presented at the 2019 PEIO Conference.

Bechtel, M. M. and Sattler, T. (2015), 'What Is Litigation in the World Trade Organization Worth?', International Organization 6(2), 375-403.

Bechtel, M. M. and Schneider, G. (2010), 'Eliciting Substance from 'Hot Air': Financial Market Responses to EU Summit Decisions on European Defense', International Organization 64(2), 199223.

Bernhagen, P. (2008), 'Business and international environmental agreements: Domestic sources of participation and compliance by advanced industrialized democracies.', Global Environmental Politics 81(1), 78-110.

Betzold, C. (2010), 'Borrowing' Power to Influence International Negotiations: AOSIS in the Climate Change Regime, 1990-1997', Politics 20(3), 131-148.

Biedenkopf, K., Mueller, P., Slominski, P. and Wettestad, J. (2017), 'A Global Turn To Greenhouse Gas Emissions Trading? Experiments, Actors, and Diffusion', Global Environmental Politics $\mathbf{1 7}(3), 1-11$.

Bovenberg, A. L. and Goulder, L. H. (2001), Behavioral and Distributional Effects of Environmental Policy, Chicago: University of Chicago Press., chapter 'Neutralizing the Adverse Industry Impacts of CO2 Abatement Policies: What Does It Cost?'.

Bulkeley, H., Andonova, L. B., Betsill, M. M. et al. (2014), Transnational Climate Change Governance, Cambridge University Press.

Bushnell, J. B., Chong, H. and Mansur, E. T. (2013), 'Profiting from Regulation: Evidence from the European Carbon Market', American Economic Journal: Economic Policy 5(4), 78-106.

Castro, P., Hoernlein, L. and Michaelowa, K. (2014), 'Constructed Peer Groups and Path Dependence in International Organizations: The Case of the International Climate Change Negotiations.', Global Environmental Change 25(109-120).

Gaikwad, N. (2013), 'Presidential prospects, political support, and stock market performance', Quarterly Journal of Political Science 8(4), 451-464.

Genovese, F. and Tvinnereim, E. (2019), 'Who Opposes Climate Regulation? Business Preferences for the European Emission Trading Scheme', The Review of International Organizations 14(3), 511542 .

Green, J. F. (2013), Rethinking Private Authority: Agents and Entrepreneurs in Global Environmental Governance, Princeton University Press.

Green, J. F. (2017), 'Don’t link carbon markets', Nature 543(7646), 484-486. 
Grubb, M. and Neuhoff, K. (2006), 'Allocation and competitiveness in the EU emissions trading scheme: Policy overview', Climate Policy 6(1), 7-30.

Gupta, J. (2010), 'A History of International Climate Change Policy', Wiley Interdisciplinary Reviews: Climate Change 1(5), 636-653.

Hale, T. (2016), “'All Hands on Deck”: The Paris Agreement and Nonstate Climate Action', Global Environmental Politics 16(3), 12-22.

Hepburn, C., Grubb, M., Neuhoff, K., Matthes, F. and Tse, M. (2006), 'Auctioning of EU ETS phase II allowances: How and why?', Climate Policy 6, 137-160.

Keohane, R. O. (1984), After Hegemony: Cooperation and Discord in the World Political Economy, Princeton University Press.

Keohane, R. O. and Victor, D. G. (2016), 'Cooperation and discord in global climate policy', Nature Climate Change 6, 570-575.

Kim, S. E., Urpelainen, J. and Yang, J. (2016), 'Electric Utilities and American Climate Policy: Lobbying by Expected Winners and Losers', Journal of Public Policy 36(2), 251-175.

Koch, N., Fuss, S., Grosjean, G. and Edenhofer, O. (2014), 'Causes of the EU ETS price drop: Recession, CDM, renewable policies or a bit of everything? New evidence', Energy Policy 73(676$685)$.

Martin, R., Muuls, M. and Wagner, U. J. (2015), Emissions Trading as a Policy Instrument: Evaluation and Prospects, MIT Press, chapter Trading Behavior in the EU Emissions Trading Scheme.

Meckling, J. (2011), Carbon Coalitions: Business, Climate Politics and the Rise of Emissions Trading, Cambridge MA: MIT Press.

Newell, P. and Paterson, M. (2010), Climate Capitalism: Global Warming and the Transformation of the Global Economy, Cambridge University Press.

Newell, R. G. (2010), 'The role of markets and policies in delivering innovation for climate change mitigation', Oxford Review of Economic Policy, 26,(2), 253-269.

Oestreich, A. M. and Tsiakas, I. (2015), 'Carbon Emissions and Stock Returns: Evidence from the EU Emissions Trading Scheme', Journal of Banking and Finance 58, 294-308.

Sattler, T. (2013), 'Do Markets Punish Left Governments?', The Journal of Politics 75(2), 343-356.

Simmons, B. (2001), 'The International Politics of Harmonization: The Case of Capital Market Regulation', International Organization 55(3), 589-620.

Victor, D. (2011), Global Warming Gridlock: Creating More Effective Strategies for Protecting the Planet, Cambridge University Press.

Victor, D. and House, J. (2004), 'A new currency: Climate change and carbon credits', Harvard International Review 26(2), 56-59. 
Vogel, D. (1995), Trading Up: Consumer and Environmental Regulation in a Global Economy, Cambridge, Mass.: Harvard University Press.

Wilf, M. (2016), 'Credibility and Distributional Effects of International Banking Regulations: Evidence from US Bank Stock Returns', International Organization 70(4), 736-796. 
Figure 1: Characteristics of the Sampled EU ETS Firms
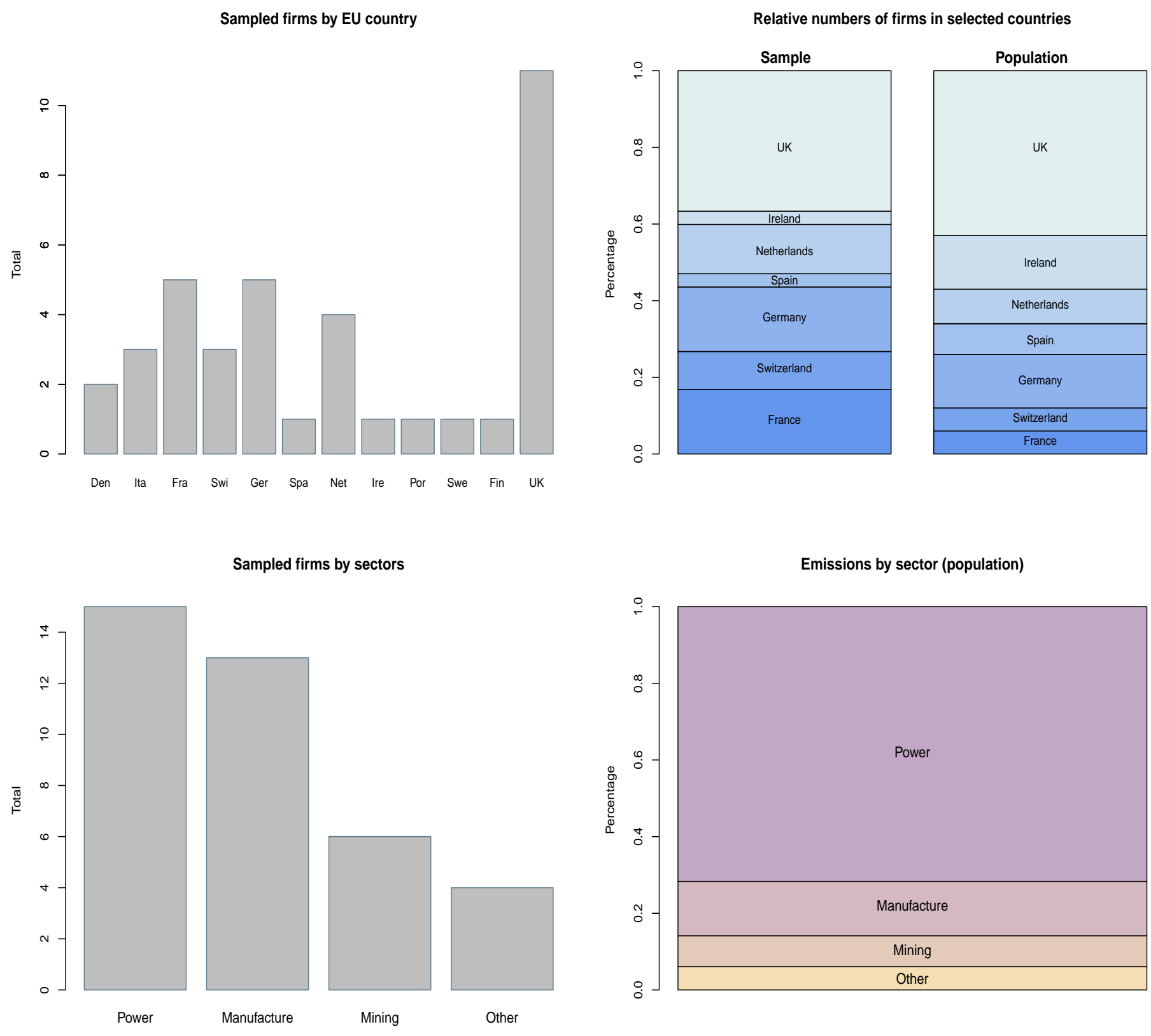

Sampled firms by sectors

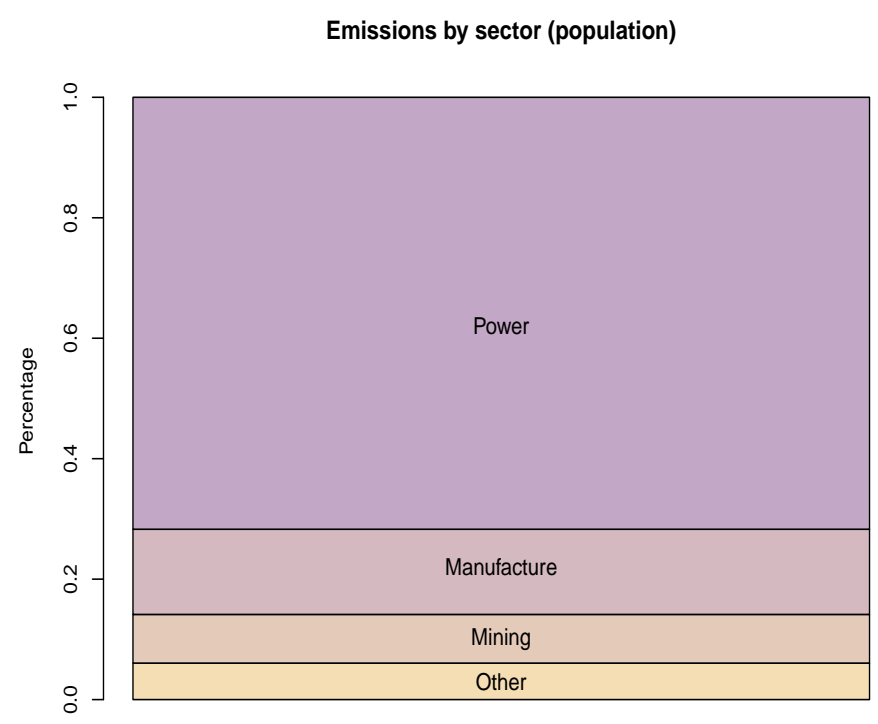

This plot describes the selected EU ETS firms according to their distribution by country and sector. The top left shows the distribution of firms' headquarters. The top right panel reports the densities of these firms for the most investment-rich countries, and compares these proportions to the actual numbers of firms located in those same countries (data from the Financial Times fDi Markets database). The bottom left histogram shows the distribution of firms based on their industries defined with UN International Standard Industrial Classification (ISIC) categories. The bottom right plot shows the 2012 emissions proportions from the covered EU ETS sectors. 
Figure 2: EU ETS Price Trends and International Climate Negotiations

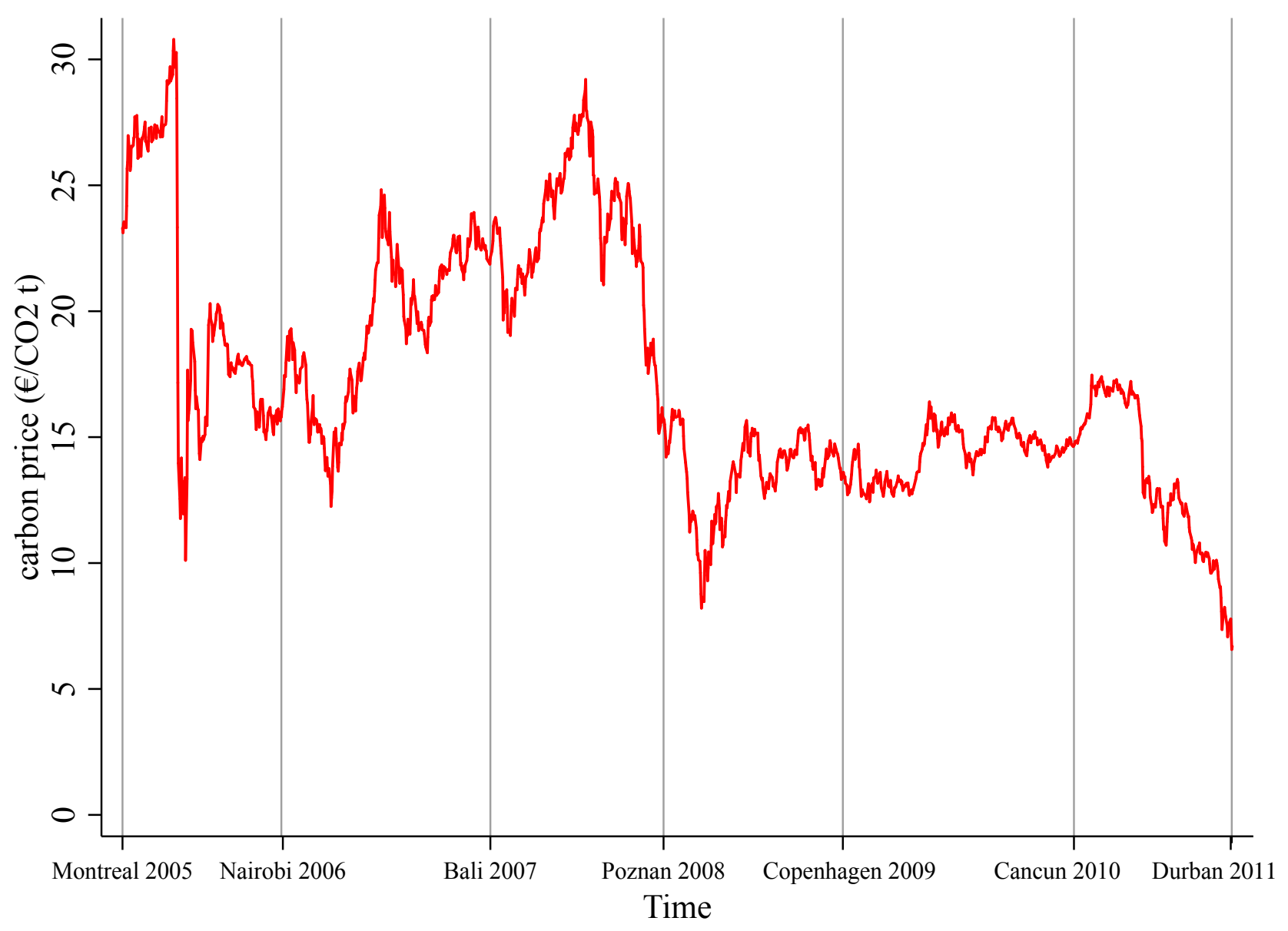

This plot shows the historical series of European Union Allowance daily prices between 2005 and 2011 (source: the Intercontinental Exchange, ICE). Future prices of Phase I allowances are expressed until April 2006. Future prices of Phase II allowances follow (as per Bushnell et al. 2013). Bars corresponds to the first day of each high-level segment of the Conference of the Parties (COP). 
Figure 3: EU ETS Average Returns and Prices, 2005-2007
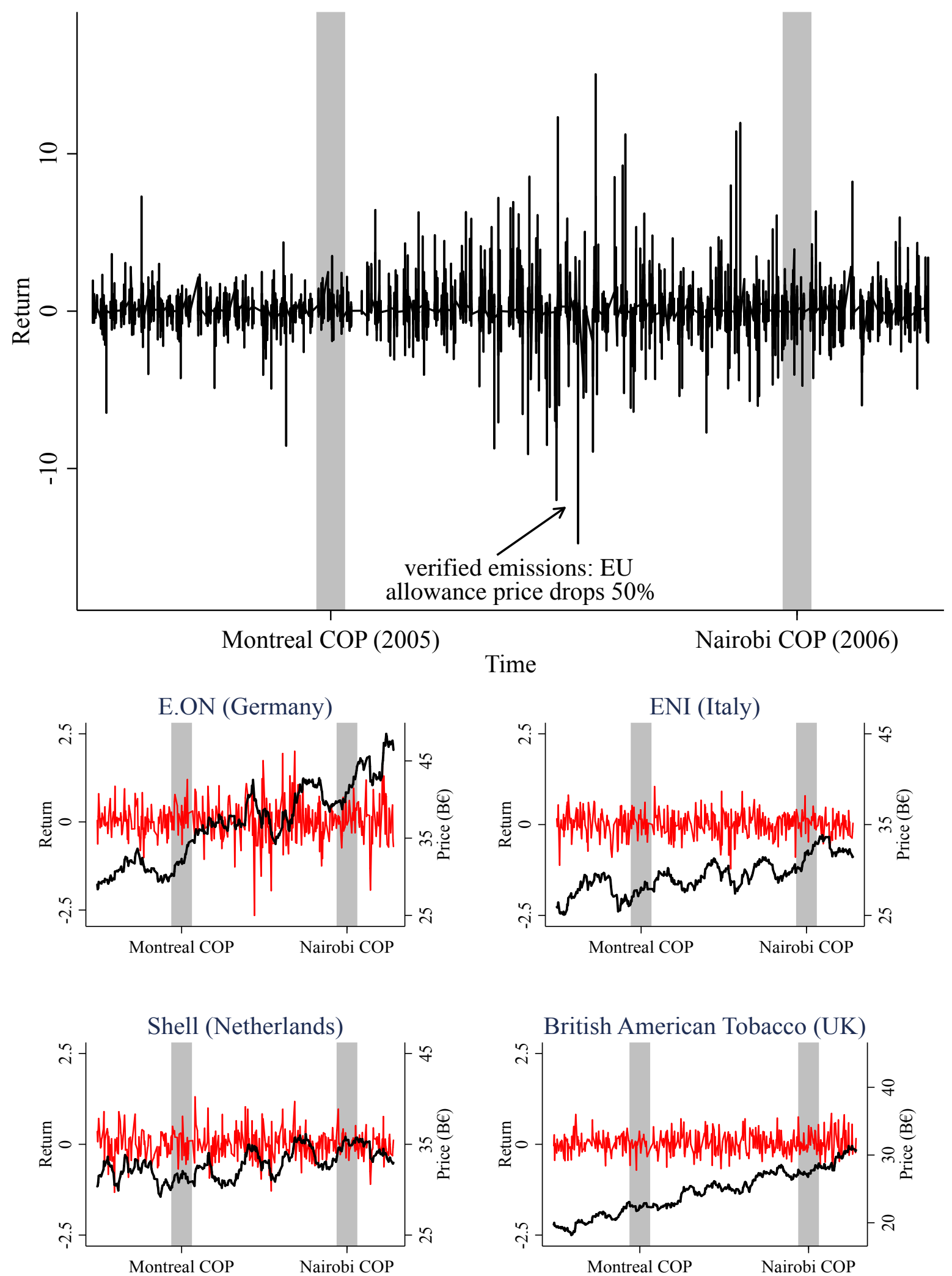

The figure illustrates patterns related to the outcome variables of the paper. The top plot shows the average stock return of the 38 selected EU ETS firms, while the bottom plots the stock return (red) and price series (black) for four specific firms. The arrow notes the variation when the first verified emissions from the Phase I were released, though this is outside of the scope of this paper. 
Figure 4: The Impact of UNFCCC Decisions About Abatement Credits ('Good UNFCCC Outcomes') on EU ETS returns, 2005-07

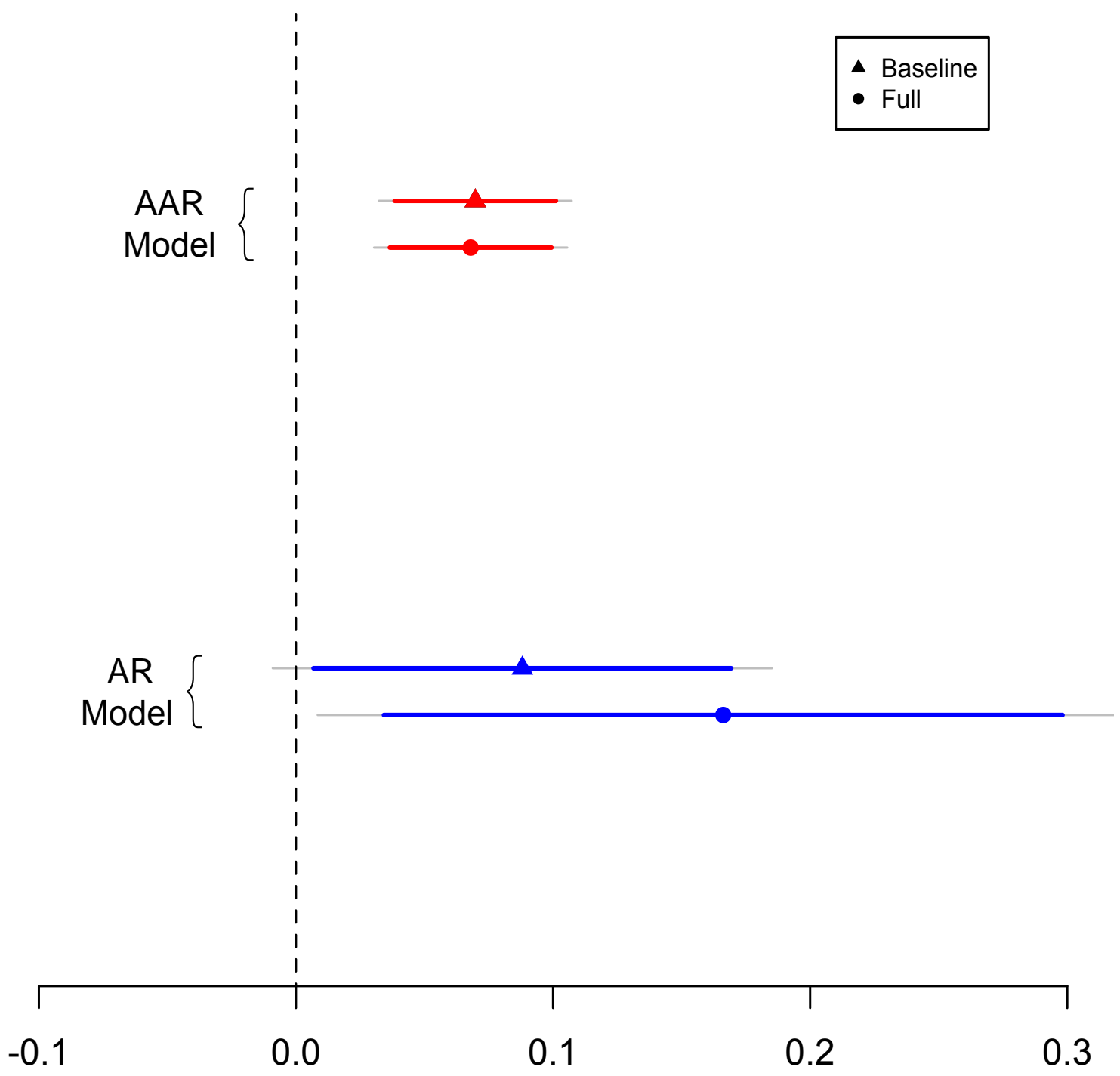

Change in Abnormal Returns, 2005-07

The figure illustrates the results of four fixed effects linear models estimated on the 2005-2007 data. The outcome variable for the two models at the top is the firms' Average Abnormal Returns, while the outcome variable for the two models at the bottom is the firms' Abnormal Returns. 'Baseline' corresponds to coefficients from a model without the control variables described in the text; 'Full' corresponds to coefficients from a fully specified model estimated with the control variables. Each dot corresponds to the estimated coefficient of Good UNFCCC Outcome for each of the model. The grey and coloured lines correspond to the $95 \%$ and $90 \%$ confidence intervals, respectively. See Appendix for the regression tables with the complete set of estimated parameters. 
Figure 5: The Impact of UNFCCC Decisions About Abatement Credits ('Good UNFCCC Outcomes') on EU ETS returns, 2008-2010

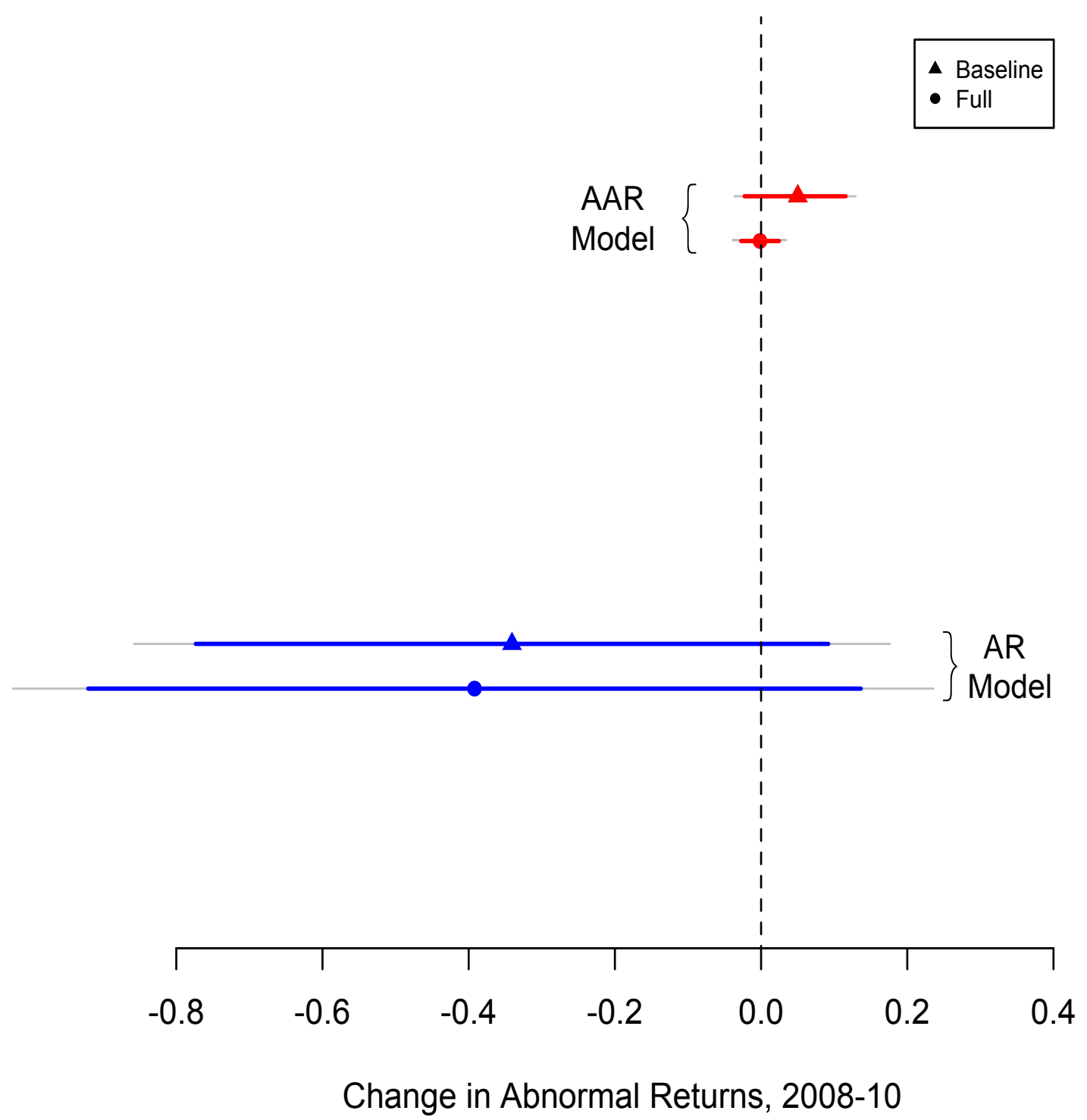

The figure illustrates the results of four fixed effects linear models estimated on the 2008-2010 data. 
Figure 6: The Impact of UNFCCC Decisions About Abatement Credits ('Good UNFCCC Outcomes') on non-European returns, 2005-2007

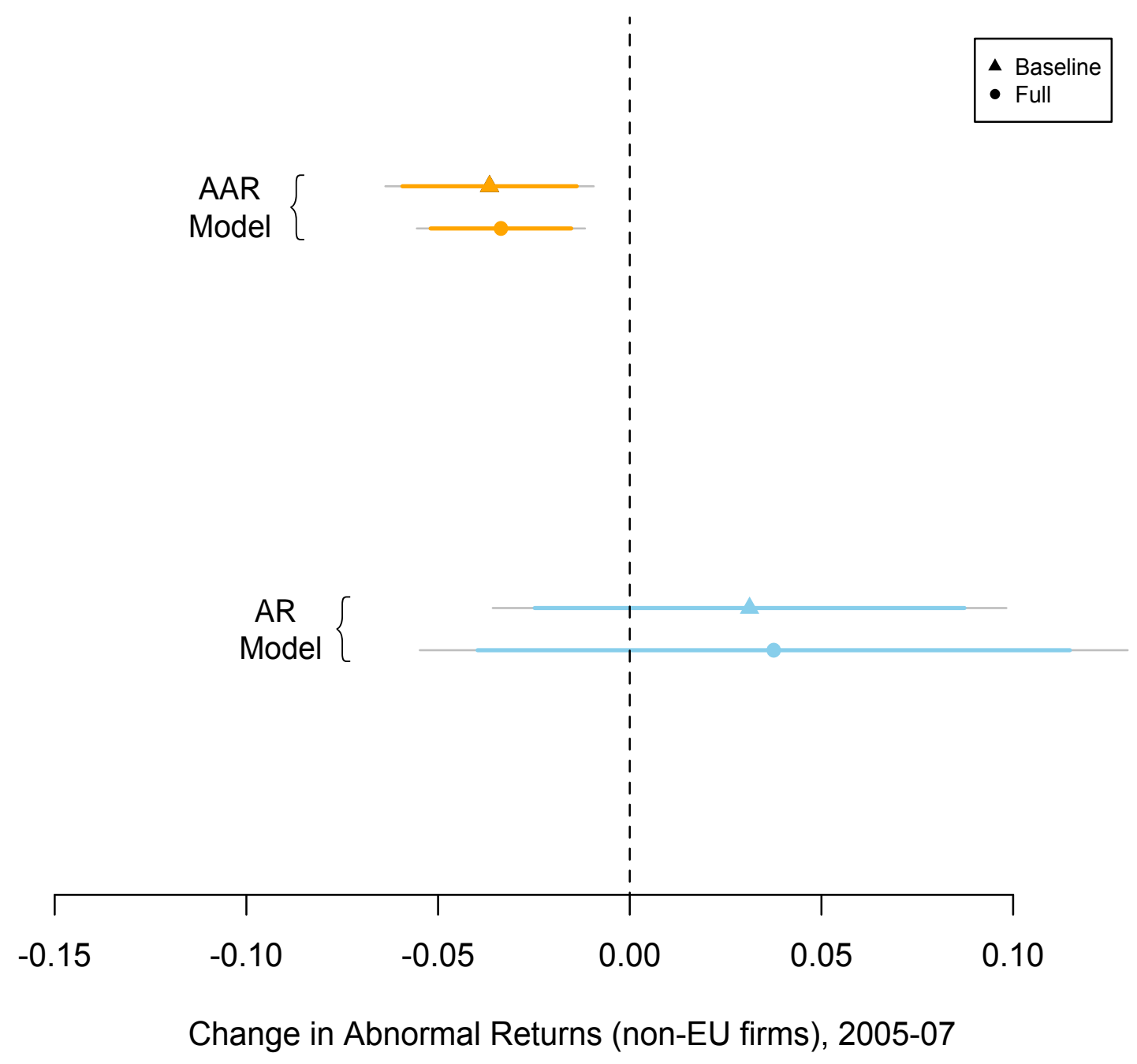

The figure illustrates the results of four fixed effects linear models run on the 2005-2007 data of the matching non-EU firms. 
Table 1: Selected UNFCCC Meetings and EU ETS-Relevant Agreements

\begin{tabular}{|c|c|c|}
\hline $\begin{array}{l}\text { COP meeting } \\
\text { (Dates) }\end{array}$ & $\begin{array}{c}\text { Decisions related to } \\
\text { tradable abatement credits }\end{array}$ & $\begin{array}{l}\text { Theorized overall effect on } \\
\text { returns of EU ETS firms }\end{array}$ \\
\hline $\begin{array}{c}\text { Montreal } \\
(28 \text { Nov }-9 \text { Dec 2005) }\end{array}$ & $\begin{array}{l}\text { Assignment of tradable credits from land use } \\
\text { for 1st commitment period, and } \\
\text { linkage of ETS to CDM ('CDM rule'). }\end{array}$ & positive \\
\hline $\begin{array}{c}\text { Nairobi } \\
(6 \text { Nov }-17 \text { Nov 2006) }\end{array}$ & $\begin{array}{c}\text { Issuance of } 18.8 \mathrm{~m} \text { Certified Emission } \\
\text { Reductions (CERs), and designation of } 17 \\
\text { operational credit entities. }\end{array}$ & positive \\
\hline $\begin{array}{c}\text { Bali } \\
\text { (3 Dec }-15 \text { Dec 2007) }\end{array}$ & $\begin{array}{c}\text { Annex B parties can participate } \\
\text { in EU ETS with CERs; quantitative } \\
\text { limit on the procurement of credits is unspecified. }\end{array}$ & mixed/null \\
\hline $\begin{array}{c}\text { Poznan } \\
\text { (1 Dec - 13 Dec 2008) }\end{array}$ & $\begin{array}{l}\text { Assignment of tradable credits from land use } \\
\text { for } 2 \text { nd commitment period, but } \\
\text { restriction on CER-based levy for adaptation. }\end{array}$ & mixed/null \\
\hline $\begin{array}{c}\text { Copenhagen } \\
\text { (7 Dec - } 18 \text { Dec 2009) }\end{array}$ & $\begin{array}{l}\text { No decision on extending emissions } \\
\text { trading to developing countries nor on additional } \\
\text { contributions to Adaptation Fund through CERs. }\end{array}$ & negative/null \\
\hline $\begin{array}{c}\text { Cancun } \\
\text { (29 Nov - } 10 \text { Dec 2010) }\end{array}$ & $\begin{array}{l}\text { Inclusion of REDD+ in CDM } \\
\text { for CERs, but no extension to EU ETS. }\end{array}$ & mixed/null \\
\hline
\end{tabular}

This table illustrates the dates of the COPs between 2005 and 2010, the relevant decisions for EU ETS firms, and the theorized effect that these decisions should have on returns of EU ETS firms. See Table A.2 in the Appendix for a detailed report of the specific decisions as worded in the Earth Negotiations Bulletin summaries. 
Table 2: Emission Trading Opinions among Firms: Link between EU ETS Allowances and International Abatement Credits

\begin{tabular}{|c|c|c|c|}
\hline & $\begin{array}{c}\text { (1) } \\
Y: C D M / J I \text { projects will eliminate need } \\
\text { for internal abatement in EU ETS } \\
\text { (Survey year: 2007) }\end{array}$ & $\begin{array}{r}(2) \\
Y: C D M / J I \text { is the } \\
\text { way to redu } \\
\text { (Survey year: 2007) }\end{array}$ & $\begin{array}{l}\text { (S3) } \\
\text { most cost-efficient } \\
\text { ce emissions } \\
\text { (Survey year: 2013) }\end{array}$ \\
\hline EU ETS regulated & $\begin{array}{l}0.36^{*} \\
(0.21)\end{array}$ & $\begin{array}{c}0.26^{* *} \\
(0.050)\end{array}$ & $\begin{array}{l}1.90^{*} \\
(0.75)\end{array}$ \\
\hline Emissions: $0.1-0.5 \mathrm{Mt}$ & $\begin{array}{c}-0.60^{* *} \\
(0.26)\end{array}$ & $\begin{array}{c}0.006 \\
(0.055)\end{array}$ & \\
\hline Emissions: $0.5-1.0 \mathrm{Mt}$ & $\begin{array}{c}0.14 \\
(0.39)\end{array}$ & $\begin{array}{c}-0.15^{* *} \\
(0.047)\end{array}$ & $\begin{array}{l}-0.81 \\
(0.55)\end{array}$ \\
\hline Emissions: $1.0-5.0 \mathrm{Mt}$ & $\begin{array}{c}-0.60^{* *} \\
(0.28)\end{array}$ & $\begin{array}{c}-0.30^{*} \\
(0.11)\end{array}$ & $\begin{array}{c}1.24^{* * *} \\
(0.18)\end{array}$ \\
\hline Emissions: $5.0-10.0 \mathrm{Mt}$ & $\begin{array}{c}-0.62^{*} \\
(0.38)\end{array}$ & $\begin{array}{l}0.034 \\
(0.15)\end{array}$ & $\begin{array}{l}-1.53^{*} \\
(0.61)\end{array}$ \\
\hline Emissions: $>10 \mathrm{Mt}$ & $\begin{array}{l}-0.59 \\
(0.37)\end{array}$ & $\begin{array}{c}0.14 \\
(0.095)\end{array}$ & $\begin{array}{l}0.086 \\
(0.21)\end{array}$ \\
\hline Constant & $\begin{array}{c}-0.67^{* * *} \\
(0.26)\end{array}$ & $\begin{array}{c}2.59^{* * *} \\
(0.20)\end{array}$ & $\begin{array}{c}1.63 \\
(0.81)\end{array}$ \\
\hline $\begin{array}{l}\text { Sector dummies } \\
\text { Country dummies }\end{array}$ & $\begin{array}{l}\checkmark \\
\checkmark\end{array}$ & $\begin{array}{l}\checkmark \\
\checkmark\end{array}$ & $\begin{array}{l}\checkmark \\
\checkmark\end{array}$ \\
\hline $\begin{array}{l}\mathrm{N} \\
\text { Log-likelihood }\end{array}$ & $\begin{array}{c}384 \\
-180.4\end{array}$ & $\begin{array}{c}380 \\
-552.4\end{array}$ & $\begin{array}{c}40 \\
-29.8\end{array}$ \\
\hline
\end{tabular}

The first model reports coefficients from a probit model (Y: 1 'yes' or 0 'no'), while the second and third models report coefficients from a linear model (Y: 1 'completely disagree' to 5 'completely agree'). Reference category for the Emissions variable is ' 0 ' for 2007 year, while it is ' $0-0.5 \mathrm{Mt}$ ' for the 2013 year. Standard errors are clustered at the country level. ${ }^{*} p<.1,{ }^{* *} p<.05,{ }^{* * *} p<.01$. 


\section{Appendix}

\section{Market Responses to Global Governance: International Climate Cooperation and Europe's Carbon Trading}

\section{Impact of Emissions Regulations on Firm Profits as Emissions Al- lowances Vary}

To clarify how global multilateral decisions related to the supply of international carbon credits can affect the profit of private firms regulated by cap-and-trade in Europe, consider European firm $i$ producing in the EU market. The market is represented by the demand curve, $\mathrm{P}\left(\mathrm{q}_{i}+\mathrm{q}_{\neq i}\right)$, where $\mathrm{q}_{\neq i}$ represents total production by other firms. The total cost of production is $\mathrm{C}_{i}$. Each regulated firm is subject to a trading scheme of greenhouse gas emissions, which is a function of its emissions rate, $r_{i}$, its total production, $\mathrm{q}_{i}$, and level of abatement, $\mathrm{I}_{i}$ (Bushnell et al 2013).

Under cap-and-trade the level of abatement determines an emission rate $r_{i}\left(\mathrm{q}_{i}, \mathrm{I}_{i}\right)$, and an abatement cost, $\mathrm{k}\left(\mathrm{I}_{i}\right)$. Now assume that the per-unit price of emissions allowances is $\tau$, a direct compliance costs. If the firm possesses allowances $\mathrm{A}_{i}$ equal to its initial allocation less net sales, considering both input and environmental costs the profits of firm i can be represented as $\pi$.

$$
\pi_{i}=\mathrm{P}\left(\mathrm{q}_{i}+\mathrm{q}_{\neq i}\right) \mathrm{q}_{i}-\mathrm{C}_{i}\left(\mathrm{q}_{i}\right)+\tau \mathrm{A}_{i}-\tau r_{i}\left(\mathrm{q}_{i}, \mathrm{I}_{i}\right) \mathrm{q}_{i}-\mathrm{k}\left(\mathrm{I}_{i}\right)
$$

An exogenous shock to permit prices that does not hurt production costs but, de facto, strengthens options for zero-cost abatement should increase the profits of firm $i$, because the derivative for profits $\left(\delta \pi_{i} / \delta \tau\right)$ are always positive with positive quantities of allowances $\mathrm{A}_{i}$. Thus, an event that provides a firm with always-cheaper options for status-quo production should boost the firm stock value, ceteris paribus. 
Table A.1: Sampled EU ETS companies

$\begin{array}{cc}\text { ATKINS } & \text { EADS } \\ \text { ASTRAZENECA } & \text { ERAMET } \\ \text { BAE SYSTEMS } & \text { EIFFAGE } \\ \text { BRITISH AMERICAN TOBACCO } & \text { AKZO NOBEL } \\ \text { BG GROUP } & \text { ENEL } \\ \text { BHP BILLITON } & \text { ENI } \\ \text { BP } & \text { FORTUM } \\ \text { CENTRICA } & \text { CIMPOR } \\ \text { CRH } & \text { EDP ENERGIAS DE PORTUGAL } \\ \text { BMW } & \text { KONINKLIJKE DSM } \\ \text { CONTINENTAL } & \text { ABB } \\ \text { CLARIANT } & \text { CIBA N } \\ \text { E ON } & \text { SHELL } \\ \text { FRESENIUS } & \text { ATEL HOLDING } \\ \text { DIAGEO } & \text { BOLIDEN } \\ \text { DANISCO } & \text { MOLLER - MAERSK } \\ \text { ACERINOX } & \text { AIR LIQUIDE } \\ \text { AIR LIQUIDE } & \text { ALSTOM } \\ \text { ALSTOM } & \text { DANONE }\end{array}$

This table lists the 38 selected EU ETS firms analyzed in this paper. 
Table A.2: Coding of the UNFCCC Outcome Variable: Emission Trading Scheme Debates at the UNFCCC and Excerpts from the Earth Negotiations Bulletin

\begin{tabular}{|c|c|c|}
\hline Date & Decision Excerpt & Outcome (Code) \\
\hline 28 November 2005 & $\begin{array}{l}\text { COP 11's agenda included items on capacity building and technology } \\
\text { transfer, the adverse effects of climate change on developing and least } \\
\text { developed countries, and several financial and budget related issues, } \\
\text { including the report of the Global Environment Facility [its impacts } \\
\text { on capacity building]. [...] Parties took decisions on technology trans- } \\
\text { fer, LULUCF, the UNFCCC's financial mechanisms, and education, } \\
\text { training and public awareness. }\end{array}$ & $\begin{array}{l}\text { Agreement on support } \\
\text { for capacity building for } \\
\text { emission trading credits } \\
(\text { Good Outcome }=1 \text { ) }\end{array}$ \\
\hline 30 November 2005 & $\begin{array}{l}\text { On implications of the establishment of new facilities to ob- } \\
\text { tain credits under the CDM for the destruction of HFC- } 23 \\
\text { (FCCC/SBSTA/2005/INF. } 8 \text { and /MISC. } 10 \text { and /MISC.11), Parties } \\
\text { stressed the need to [proceed with financial mechanisms and] avoid } \\
\text { perverse incentives. }\end{array}$ & $\begin{array}{l}\text { Agreement on sustain- } \\
\text { ing credit provision } \\
\text { via CDM integration } \\
(\text { Good Outcome }=1)\end{array}$ \\
\hline 1 December 2005 & $\begin{array}{l}\text { The delegates noted the linking of the EU emissions trading scheme } \\
\text { to the Kyoto mechanisms, and concerns that the CDM process needs } \\
\text { to be improved to deliver projects and CERs on the scale sought by } \\
\text { Parties. }\end{array}$ & $\begin{array}{l}\text { Agreement on } \text { sustain- } \\
\text { ing credit provision } \\
\text { via CDM integration } \\
(\text { Good Outcome }=1)\end{array}$ \\
\hline 6 December 2005 & $\begin{array}{l}\text { The Co-Chairs introduced a draft decision, noting that while the } \\
\text { decision would apply, mutatis mutandis, the MOU with respect to } \\
\text { guidance to the entity entrusted with the operation of the financial } \\
\text { mechanism of the Convention, it would not apply to the Adaptation } \\
\text { Fund, as no decision has been taken on the operational entity for } \\
\text { that fund.ă[... Highlighting the need to assist vulnerable countries, } \\
\text { developing countries suggested levying } 2 \% \text { of JI Emissions Reduction } \\
\text { Units (ERUs) for the Adaptation Fund. }\end{array}$ & $\begin{array}{l}\text { Agreement on sustain- } \\
\text { ing credit provision } \\
\text { via CDM integration } \\
(\text { Good Outcome }=1)\end{array}$ \\
\hline 14 November 2006 & $\begin{array}{l}\text { The contact group convened briefly in the evening to introduce the } \\
\text { Co-Chairs' draft conclusions on the GEF's report to the COP; a draft } \\
\text { decision on the review of the financial mechanism; and a draft decision } \\
\text { on additional guidance to the GEF. }\end{array}$ & $\begin{array}{l}\text { Agreement on support } \\
\text { for capacity building for } \\
\text { emission trading credits } \\
\text { (Good Outcome }=1 \text { ) }\end{array}$ \\
\hline 15 November 2006 & $\begin{array}{l}\text { Tina Guthrie (Canada) reported on the outcomes of the contact } \\
\text { group where delegates resolved the outstanding issue on the fourth } \\
\text { review of the financial mechanism. [...] With agreement on the major- } \\
\text { ity of items under the financial mechanism, some delegates reportedly } \\
\text { glimpsed the first steps in the confidence building process that will } \\
\text { be required to pull together a post- } 2012 \text { regime. }\end{array}$ & $\begin{array}{l}\text { Agreement on sustain- } \\
\text { ing credit provision } \\
(\text { Good Outcome }=1)\end{array}$ \\
\hline $\begin{array}{l}17 \text { November } 2006 \\
\text { (from ENB summary } \\
\text { of } 20 \quad \text { November } \\
2008)\end{array}$ & $\begin{array}{l}\text { The group] welcomes the fact that Belarus will use any revenue gen- } \\
\text { erated under emissions trading for further greenhouse gas abatement } \\
\text { measures, subject to approval by the relevant authorities in the coun- } \\
\text { try. [...] The EU emissions trading scheme is likely to form the } \\
\text { cornerstone of a global scheme. [...] Parties agreed on the need to } \\
\text { continue deliberating on this option, but disagreements surfaced on } \\
\text { the institutions to which the CERs would be issued, and on what } \\
\text { to do with the 'remaining' credits left after the project costs were } \\
\text { met. [...] China supported issuing the credits to the host govern- } \\
\text { ment account rather than to another institution and that the credits } \\
\text { be used to fund other activities beneficial to the global environment. } \\
{[\ldots] \text { Brazil, the EU and others supported issuing the credits to an- }} \\
\text { other institution and either canceling the credits or using them to } \\
\text { fund activities that include means to phase out the production and } \\
\text { consumption of HCFCs. }\end{array}$ & $\begin{array}{l}\text { Agreement on sustain- } \\
\text { ing credit provision } \\
(\text { Good Outcome }=1)\end{array}$ \\
\hline
\end{tabular}

continues 


\begin{tabular}{|c|c|c|}
\hline Date & Decision Excerpt & Outcome (Code) \\
\hline 8 December 2007 & $\begin{array}{l}\text { Delegates discussed issues such as costs, the inclusion of non-CO2 } \\
\text { gases in the EU Emissions Trading Scheme (ETS), and the agriculture } \\
\text { sector. [...] Senegal, Argentina and others opposed crediting the } \\
\text { destruction of HFC-23 in new facilities under the CDM. }\end{array}$ & $\begin{array}{l}\text { Partial agreement on } \\
\text { capacity building; dis- } \\
\text { agreement on sectoral } \\
\text { divisions of credits } \\
(\text { Good Outcome }=0)\end{array}$ \\
\hline $\begin{array}{l}15 \text { December } 2007 \\
\text { (from ENB summary } \\
\text { of } 18 \text { December } \\
2007)\end{array}$ & $\begin{array}{l}\text { While parties agreed to request submissions on extending the share } \\
\text { of proceeds to JI and emissions trading, Ukraine and the Russian } \\
\text { Federation expressed reservations at the closing plenary, stating that } \\
\text { this proposal would hinder the implementation of these mechanisms } \\
\text { in their countries }\end{array}$ & $\begin{array}{l}\text { Partial agreement on } \\
\text { capacity building; dis- } \\
\text { agreement on sectoral } \\
\text { divisions of credits } \\
(\text { Good Outcome }=0)\end{array}$ \\
\hline 2-3 December 2008 & $\begin{array}{l}\text { The Least Developed Countries (LDCs) supported enhancing the fi- } \\
\text { nancial mechanism under the COP, and highlighted the importance } \\
\text { of national adaptation programmes of action (NAPAs). }\end{array}$ & $\begin{array}{l}\text { Agreement on support } \\
\text { for capacity building for } \\
\text { emission trading credits } \\
(\text { Good Outcome }=1)\end{array}$ \\
\hline 4 December 2008 & $\begin{array}{l}\text { In the contact group, delegates discussed the heavily bracketed text } \\
\text { for a draft decision on the fourth review compiled at SBI } 28 \text {. China } \\
\text { and South Africa supported simplifying accreditation of Designated } \\
\text { Operational Entities (DOEs) and China and others called for more } \\
\text { transparency. The EU warned that reduction goals could be weak- } \\
\text { ened depending on the rules adopted for LULUCF, carbon credits } \\
\text { and bunker fuels. }\end{array}$ & $\begin{array}{l}\text { Agreement on sustaining } \\
\text { credit provision via au- } \\
\text { ditors } \\
\text { Outcome }=1 \text { (Good }\end{array}$ \\
\hline 10 December 2008 & $\begin{array}{l}\text { Delegates met on Tuesday afternoon to consider a new draft text, } \\
\text { which contains, inter alia: three different options on extending the } \\
\text { share of proceeds to JI and emissions trading. [...] The mood seemed } \\
\text { less upbeat, with some frustration expressed after talks bogged down } \\
\text { on the financial mechanism, Adaptation Fund and LDC Fund. [...] } \\
\text { Informal consultations focusing on the operational aspects and dis- } \\
\text { tribution of CDM projects continued on Tuesday, based on a new } \\
\text { draft text addressing, inter alia, transparency of the CDM Executive } \\
\text { Board's decision making, accreditation of DOEs and application of } \\
\text { financial penalties to non-complying DOEs. }\end{array}$ & $\begin{array}{l}\text { Disagreement on } \\
\text { credit } \quad \text { provision } \\
(\text { Good Outcome }=-1)\end{array}$ \\
\hline $\begin{array}{l}13 \text { December } 2008 \\
\text { (from ENB summary } \\
\text { of } 15 \quad \text { December } \\
2008)\end{array}$ & $\begin{array}{l}\text { [There was] lack of agreement on extending the share of proceeds (or } \\
\text { "adaptation levy") to Joint Implementation and emissions trading } \\
\text { under the second review of the Protocol under Article 9. [...] Devel- } \\
\text { oped countries generally expressed their satisfaction with the GEF's } \\
\text { performance, while developing countries had numerous concerns, par- } \\
\text { ticularly with regard to the GEF's fifth replenishment, complemen- } \\
\text { tarity of the financial mechanism to other sources of financing, pro- } \\
\text { liferation of funds outside of the Convention and outcomes of the } \\
\text { mid-term review of the Resource Allocation Framework (RAF). }\end{array}$ & $\begin{array}{l}\text { Disagreement on } \\
\text { credit provision } \\
(\text { Good Outcome }=-1)\end{array}$ \\
\hline
\end{tabular}




\begin{tabular}{|c|c|c|}
\hline Date & Decision Excerpt & Outcome (Code) \\
\hline December & $\begin{array}{l}\text { On the fourth review of the financial mechanism, the EU proposed } \\
\text { streamlining the draft conclusions. [... The EU representative] high- } \\
\text { lighted actions taken to operationalize the Adaptation Fund, includ- } \\
\text { ing: adoption of policies and guidelines for accessing funds; com- } \\
\text { mencement of the monetization of Certified Emission Reductions } \\
\text { (CERs); and the decision to accept Germany's offer to confer le- } \\
\text { gal capacity on and host the Board. [...] Some parties preferred to } \\
\text { house a matching function or registry within a financial mechanism, } \\
\text { while others said that matching functions should remain within the } \\
\text { purview of the drafting group [...] Co-Chair Lei noted progress made } \\
\text { under this agenda item but said that the contact group needs more } \\
\text { time to finish its work. }\end{array}$ & $\begin{array}{l}\text { Partial agreement } \\
\text { on capacity building } \\
\text { and issuing of credits } \\
(\text { Good Outcome }=0)\end{array}$ \\
\hline 15 December 2009 & $\begin{array}{l}\text { On emissions trading, New Zealand noted interest in extending emis- } \\
\text { sions trading to developing countries and proposed text reflecting } \\
\text { this. The EU, supported by NEW ZEALAND and others, proposed } \\
\text { a paragraph establishing new market-based mechanisms. This was } \\
\text { opposed by ARGENTINA and VENEZUELA. [...] Venezuela op- } \\
\text { posed the establishment of new market-based-mechanisms and pro- } \\
\text { posed inserting a footnote stating that this would require a Protocol } \\
\text { amendment, and also noted that this issue is being addressed under } \\
\text { the AWG-LCA. }\end{array}$ & $\begin{array}{l}\text { Disagreement } \\
\text { credit provision and } \\
\text { market integration } \\
(\text { Good Outcome }=-1 \text { ) }\end{array}$ \\
\hline 18 December 2009 & $\begin{array}{l}\text { The COP adopted a decision on the fourth review of the fi- } \\
\text { nancial mechanism referred to it by the SBI. In its decision } \\
\text { (FCCC/SBI/2009/L.29), the COP requests the SBI to continue its } \\
\text { consideration of the fourth review of the financial mechanism at SBI } \\
32 \text {, with a view to recommending a draft decision for adoption by } \\
\text { COP } 16 \text {. The COP also decides to complete the consideration of the } \\
\text { fourth review of the financial mechanism at COP } 16 \text {. }\end{array}$ & $\begin{array}{l}\text { Disagreement on credit } \\
\text { provision and market } \\
\text { integration; agreement } \\
\text { on continuing dis- } \\
\text { cussion at next COP } \\
(\text { Good Outcome }=-1)\end{array}$ \\
\hline 3-4 December 2010 & $\begin{array}{l}\text { [...] Parties discussed whether progress could be made on various is- } \\
\text { sues including: nuclear power under the CDM; use of standardized } \\
\text { baselines; co-benefits; use of Certified Emission Reductions (CERs) } \\
\text { from project activities in certain host countries; discount factors; } \\
\text { share of proceeds; emissions trading; and supplementarity. [...] Par- } \\
\text { ties then discussed whether credits can be issued from projects in } \\
\text { countries such as Belarus that are in the process of becoming Proto- } \\
\text { col Annex B parties. [...] AWG-KP Vice-Chair Macey said the group } \\
\text { had refined options on the possible inclusion of carbon capture and } \\
\text { storage (CCS) under the CDM and that parties are consulting on the } \\
\text { use of Certified Emission Reductions (CERs) generated from projects } \\
\text { in certain countries.ă }\end{array}$ & $\begin{array}{l}\text { Partial agreement } \\
\text { on capacity building } \\
\text { and issuing of credits } \\
(\text { Good Outcome }=0)\end{array}$ \\
\hline $\begin{array}{l}\text { 8-10 December } 2010 \\
\text { (also from ENB sum- } \\
\text { mary of } 15 \text { December } \\
2008 \text { ) }\end{array}$ & $\begin{array}{l}\text { On the flexibility mechanisms, AWG-KP Vice-Chair Adrian Macey } \\
\text { (New Zealand) highlighted the focus of discussions on enhancing co- } \\
\text { benefits under the CDM and increasing the use of Certified Emission } \\
\text { Reductions from certain host countries. [...] Parties discussed a para- } \\
\text { graph allowing crediting from JI projects after the first commitment } \\
\text { period, using Assigned Amount Units (AAUs) from the first commit- } \\
\text { ment period. Parties [engaged] in extensive debate over text dealing } \\
\text { with [...] the process and requirements for the accreditation of na- } \\
\text { tional implementing entities. [...] Going through the text, parties } \\
\text { agreed on all paragraphs apart from par. } 52 \text { on the Executive Board } \\
\text { revising the procedures for CDM project registration to allow the } \\
\text { crediting period to start from the date that a complete request for } \\
\text { registration has been submitted, which was bracketed at the request } \\
\text { of Bolivia. }\end{array}$ & $\begin{array}{l}\text { Partial agreement } \\
\text { on capacity building } \\
\text { and issuing of credits } \\
(\text { Good Outcome }=0)\end{array}$ \\
\hline
\end{tabular}


Table A.3: The impact of UNFCCC decisions on the returns of EU ETS firms, 2005-07

\begin{tabular}{|c|c|c|c|c|}
\hline & \multicolumn{2}{|c|}{$A A R_{i t}$ Models } & \multicolumn{2}{|c|}{$A R_{i t}$ Models } \\
\hline & (1) & (2) & $(3)$ & (4) \\
\hline Good UNFCCC Outcome & $\begin{array}{c}0.070^{* * *} \\
(0.019)\end{array}$ & $\begin{array}{c}0.068^{* * *} \\
(0.020)\end{array}$ & $\begin{array}{l}0.088^{+} \\
(0.050)\end{array}$ & $\begin{array}{c}0.17^{*} \\
(0.082)\end{array}$ \\
\hline National Elections & & $\begin{array}{c}0.076^{* * *} \\
(0.022)\end{array}$ & & $\begin{array}{l}-0.14^{*} \\
(0.061)\end{array}$ \\
\hline Domestic Policy & & $\begin{array}{l}0.077^{+} \\
(0.044)\end{array}$ & & $\begin{array}{l}0.37^{+} \\
(0.22)\end{array}$ \\
\hline Relevant Web Searches $\delta$ & & $\begin{array}{c}0.003^{* * *} \\
(0.008)\end{array}$ & & $\begin{array}{l}0.027^{+} \\
(0.014)\end{array}$ \\
\hline Relevant Web Searches $s_{t-1}$ & & $\begin{array}{c}0.005^{* * *} \\
(0.001)\end{array}$ & & $\begin{array}{l}0.016^{* *} \\
(0.005)\end{array}$ \\
\hline Carbon Price $\delta$ & & $\begin{array}{c}0.024^{* *} \\
(0.0078)\end{array}$ & & $\begin{array}{c}0.057 \\
(0.043)\end{array}$ \\
\hline${\text { Carbon } \text { Price }_{t-1}}$ & & $\begin{array}{c}0.026^{* *} \\
(0.0090)\end{array}$ & & $\begin{array}{c}0.11^{*} \\
(0.048)\end{array}$ \\
\hline Constant & $\begin{array}{c}-0.060^{* * *} \\
(0.004)\end{array}$ & $\begin{array}{c}-0.78^{* * *} \\
(0.23)\end{array}$ & $\begin{array}{c}-0.077^{* * *} \\
(0.0070)\end{array}$ & $\begin{array}{c}-2.68^{* *} \\
(1.03)\end{array}$ \\
\hline $\mathrm{N}$ & 1582 & 1094 & 1360 & 983 \\
\hline Firms & 38 & 38 & 38 & 38 \\
\hline Fixed effects & yes & yes & yes & yes \\
\hline $\mathrm{R}^{2}$ & 0.016 & 0.004 & 0.002 & 0.004 \\
\hline
\end{tabular}

Linear coefficients. Robust standard errors in parentheses. The outcome variable for Models 1 and 2 is $\mathrm{AAR}_{i t}$, while the outcome variable for Models 3 and 4 is $\mathrm{AR}_{i t}$. Firm, country and COP fixed effects estimated but not reported. $+p<.1,{ }^{*} p<.05,{ }^{* *} p<.01,{ }^{* * *} p<.001$. 
Table A.4: The impact of UNFCCC decisions on the returns of EU ETS firms: Alternative Event Windows, 2005-07

\begin{tabular}{|c|c|c|c|c|c|c|c|}
\hline & $\begin{array}{c}(1) \\
\text { Cop end }-3\end{array}$ & $\begin{array}{c}(2) \\
\text { Cop end -2 }\end{array}$ & $\begin{array}{c}(3) \\
\text { Cop end }-1\end{array}$ & $\begin{array}{c}4 A R_{i t} M o \\
(4) \\
\text { Cop end }\end{array}$ & $\begin{array}{l}\text { els } \\
\text { Cop end }+1\end{array}$ & $\begin{array}{c}(6) \\
\text { Cop end +2 }\end{array}$ & $\begin{array}{c}(7) \\
\text { Cop end }+3\end{array}$ \\
\hline Good UNFCCC Outcome & $\begin{array}{c}0.013 \\
(0.012)\end{array}$ & $\begin{array}{l}0.041^{* *} \\
(0.015)\end{array}$ & $\begin{array}{c}0.054^{* *} \\
(0.019)\end{array}$ & $\begin{array}{l}0.062^{* *} \\
(0.020)\end{array}$ & $\begin{array}{c}0.069^{* *} \\
(0.022)\end{array}$ & $\begin{array}{c}0.072^{* *} \\
(0.022)\end{array}$ & $\begin{array}{c}0.051^{* *} \\
(0.020)\end{array}$ \\
\hline National Elections & $\begin{array}{c}0.00 \\
(0.00)\end{array}$ & $\begin{array}{c}0.00 \\
(0.00)\end{array}$ & $\begin{array}{c}0.00 \\
(0.00)\end{array}$ & $\begin{array}{c}-0.001 \\
(0.004)\end{array}$ & $\begin{array}{l}0.013^{+} \\
(0.007)\end{array}$ & $\begin{array}{c}0.016^{*} \\
(0.006)\end{array}$ & $\begin{array}{c}0.076^{* *} \\
(0.022)\end{array}$ \\
\hline Domestic Policy & $\begin{array}{c}0.048 \\
(0.053)\end{array}$ & $\begin{array}{c}0.073 \\
(0.055)\end{array}$ & $\begin{array}{c}0.090 \\
(0.058)\end{array}$ & $\begin{array}{c}0.094 \\
(0.059)\end{array}$ & $\begin{array}{c}0.10^{+} \\
(0.060)\end{array}$ & $\begin{array}{c}0.11^{+} \\
(0.060)\end{array}$ & $\begin{array}{l}0.075^{+} \\
(0.044)\end{array}$ \\
\hline Relevant Web Searches $\delta$ & $\begin{array}{c}0.000 \\
(0.001)\end{array}$ & $\begin{array}{c}0.001 \\
(0.001)\end{array}$ & $\begin{array}{l}0.002^{+} \\
(0.001)\end{array}$ & $\begin{array}{l}0.002^{*} \\
(0.001)\end{array}$ & $\begin{array}{c}0.003^{*} \\
(0.001)\end{array}$ & $\begin{array}{c}0.003^{* *} \\
(0.001)\end{array}$ & $\begin{array}{c}0.003^{* *} \\
(0.001)\end{array}$ \\
\hline Relevant Web Searches $s_{t-1}$ & $\begin{array}{c}0.004^{*} \\
(0.002)\end{array}$ & $\begin{array}{c}0.005^{* *} \\
(0.002)\end{array}$ & $\begin{array}{c}0.005^{* *} \\
(0.002)\end{array}$ & $\begin{array}{c}0.005^{* *} \\
(0.002)\end{array}$ & $\begin{array}{c}0.005^{* *} \\
(0.002)\end{array}$ & $\begin{array}{c}0.006^{* *} \\
(0.002)\end{array}$ & $\begin{array}{c}0.005^{* *} \\
(0.001)\end{array}$ \\
\hline Carbon Price $\delta$ & $\begin{array}{c}0.001 \\
(0.008)\end{array}$ & $\begin{array}{c}0.013 \\
(0.008)\end{array}$ & $\begin{array}{l}0.019^{+} \\
(0.009)\end{array}$ & $\begin{array}{l}0.020^{*} \\
(0.009)\end{array}$ & $\begin{array}{l}0.024^{*} \\
(0.010)\end{array}$ & $\begin{array}{c}0.027^{* *} \\
(0.009)\end{array}$ & $\begin{array}{c}0.024^{* *} \\
(0.008)\end{array}$ \\
\hline Carbon Price t-1 $_{1}$ & $\begin{array}{l}0.028^{*} \\
(0.011)\end{array}$ & $\begin{array}{c}0.029^{*} \\
(0.011)\end{array}$ & $\begin{array}{l}0.029^{*} \\
(0.011)\end{array}$ & $\begin{array}{c}0.029^{* *} \\
(0.011)\end{array}$ & $\begin{array}{c}0.030^{* *} \\
(0.011)\end{array}$ & $\begin{array}{c}0.031^{* *} \\
(0.011)\end{array}$ & $\begin{array}{c}0.026^{* *} \\
(0.0089)\end{array}$ \\
\hline Constant & $\begin{array}{c}-0.72^{* *} \\
(0.25)\end{array}$ & $\begin{array}{c}-0.79^{* *} \\
(0.26)\end{array}$ & $\begin{array}{c}-0.83^{* *} \\
(0.27)\end{array}$ & $\begin{array}{c}-0.84^{* *} \\
(0.27)\end{array}$ & $\begin{array}{c}-0.87^{* *} \\
(0.28)\end{array}$ & $\begin{array}{c}-0.91^{* *} \\
(0.28)\end{array}$ & $\begin{array}{c}-0.77^{* *} \\
(0.22)\end{array}$ \\
\hline $\mathrm{N}$ & 566 & 679 & 792 & 867 & 980 & 1018 & 1094 \\
\hline Firms & 38 & 38 & 38 & 38 & 38 & 38 & 38 \\
\hline Fixed effects & yes & yes & yes & yes & yes & yes & yes \\
\hline $\mathrm{R}^{2}$ & 0.18 & 0.16 & 0.16 & 0.16 & 0.16 & 0.16 & 0.16 \\
\hline
\end{tabular}

Linear coefficients. Robust standard errors in parentheses. The outcome variable is AAR it $_{\text {. The estimations }}$ are based on the time series truncated, respectively, at 3 days before the end of the COP meeting; 2 days before the end of the COP meeting; 1 day before the end of the COP meeting, the ending day of the COP meeting; 1 day after the end of the COP meeting; 2 days after the end of the COP meeting; and 3 days after the end of the COP meeting. Firm, country and COP fixed effects estimated but not reported. $+p<.1,{ }^{*} p<.05,{ }^{* *}$ $p<.01, * * * p<.001$. 
Figure A.1: The Impact of UNFCCC Decisions About Abatement Credits ('Good Outcomes') on EU ETS returns: Time Span of the Effect

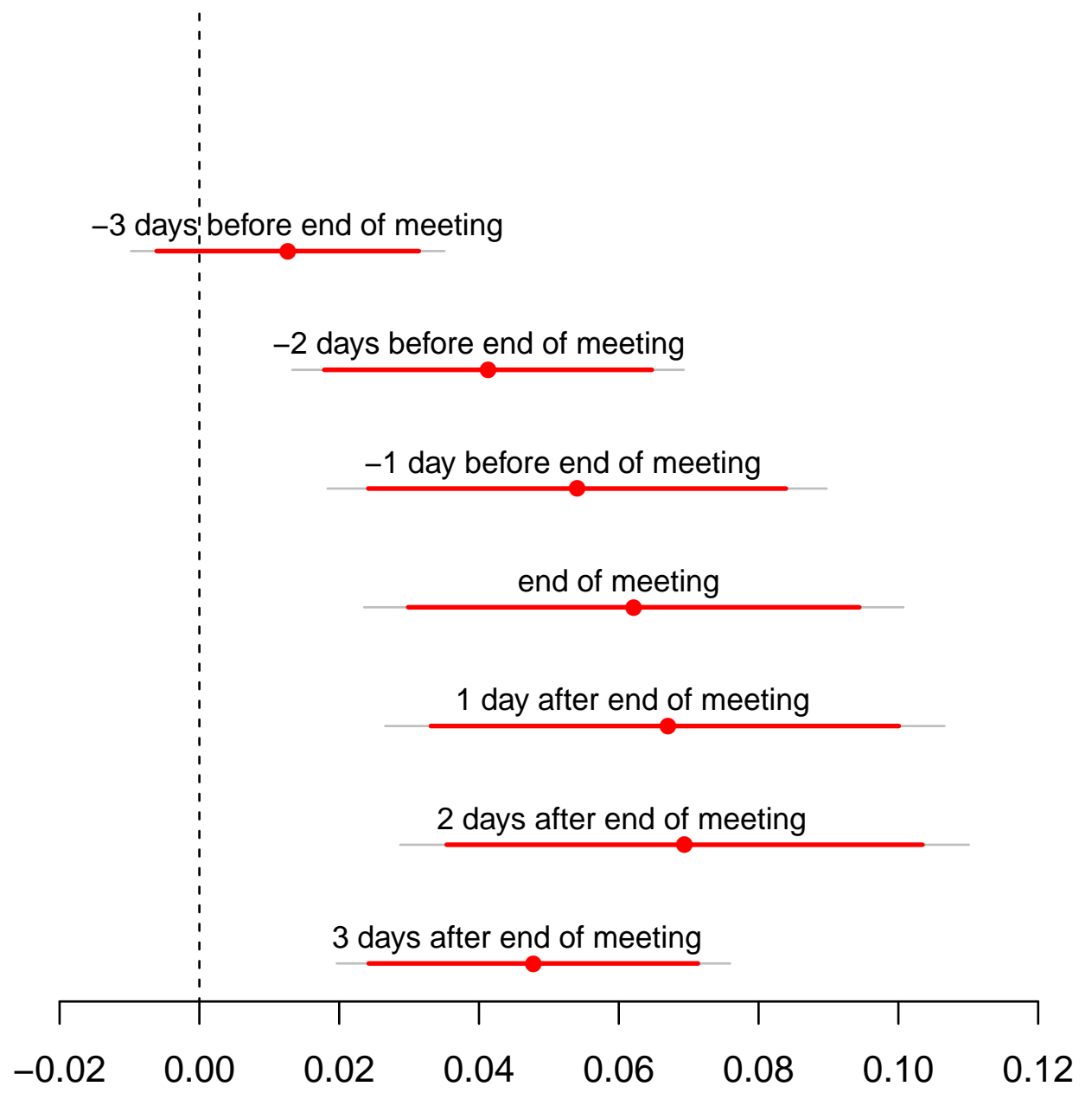

Change in Abnormal Returns, 2005-07

The figure illustrates the effect of Good UNFCCC Outcome as estimated in several fully specified linear models where the estimation window is truncated at the noted date of the COP. The outcome variable is the firms' Average Abnormal Returns. Each dot corresponds to the estimated coefficient, while the grey and coloured lines correspond to the $95 \%$ and $90 \%$ confidence intervals, respectively. See Appendix for the regression tables with the complete set of estimated parameters. 
Table A.5: The impact of UNFCCC decisions on the returns of EU ETS firms: Average Abnormal Returns by Sector, 2005-07

\begin{tabular}{|c|c|c|c|}
\hline & $\begin{array}{c}(1) \\
\text { Mining }\end{array}$ & $\begin{array}{c}A A R_{i t} \text { Models } \\
(2) \\
\text { Manufacture }\end{array}$ & $\begin{array}{c}(3) \\
\text { Power }\end{array}$ \\
\hline Good UNFCCC Outcome & $\begin{array}{c}0.11^{+} \\
(0.061)\end{array}$ & $\begin{array}{l}0.11^{* * *} \\
(0.024)\end{array}$ & $\begin{array}{l}0.054^{*} \\
(0.022)\end{array}$ \\
\hline National Elections & $\begin{array}{c}0.061 \\
(0.076)\end{array}$ & $\begin{array}{l}0.060^{*} \\
(0.030)\end{array}$ & $\begin{array}{c}0.032 \\
(0.027)\end{array}$ \\
\hline Domestic Policy & $\begin{array}{c}0.15 \\
(0.093)\end{array}$ & $\begin{array}{l}0.060^{+} \\
(0.033)\end{array}$ & $\begin{array}{l}-0.075^{*} \\
(0.031)\end{array}$ \\
\hline Relevant Web Searches $\delta$ & $\begin{array}{c}0.001 \\
(0.005)\end{array}$ & $\begin{array}{c}0.001 \\
(0.002)\end{array}$ & $\begin{array}{c}0.001 \\
(0.002)\end{array}$ \\
\hline Relevant Web Searches $s_{t-1}$ & $\begin{array}{l}0.005^{*} \\
(0.002)\end{array}$ & $\begin{array}{c}0.005^{* * *} \\
(0.001)\end{array}$ & $\begin{array}{c}0.003^{* * *} \\
(0.001)\end{array}$ \\
\hline Carbon Price $\delta$ & $\begin{array}{c}0.034 \\
(0.028)\end{array}$ & $\begin{array}{c}0.013 \\
(0.011)\end{array}$ & $\begin{array}{l}-0.006 \\
(0.010)\end{array}$ \\
\hline 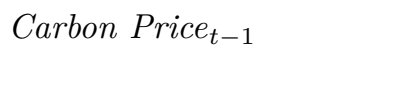 & $\begin{array}{c}0.044^{* * *} \\
(0.009)\end{array}$ & $\begin{array}{c}0.022^{* * *} \\
(0.003)\end{array}$ & $\begin{array}{r}-0.005^{+} \\
(0.003)\end{array}$ \\
\hline Constant & $\begin{array}{c}-1.19^{* * *} \\
(0.19) \\
\end{array}$ & $\begin{array}{c}-0.72^{* * *} \\
(0.070) \\
\end{array}$ & $\begin{array}{l}-0.070 \\
(0.066)\end{array}$ \\
\hline $\mathrm{N}$ & 203 & 377 & 398 \\
\hline Firms & 7 & 13 & 14 \\
\hline $\begin{array}{l}\text { Fixed effects } \\
\mathrm{R}^{2}\end{array}$ & $\begin{array}{c}\text { yes } \\
0.18\end{array}$ & $\begin{array}{c}\text { yes } \\
0.28\end{array}$ & $\begin{array}{c}\text { yes } \\
0.098\end{array}$ \\
\hline
\end{tabular}

Linear coefficients. Robust standard errors in parentheses. The outcome variable is $\mathrm{AAR}_{i t}$. Firm and country fixed effects estimated but not reported. $+p<.1,{ }^{*} p<.05,{ }^{* *} p<.01,{ }^{* * *} p<.001$. 
Figure A.2: The Impact of UNFCCC Decisions About Abatement Credits ('Good Outcomes') on EU ETS returns: Subgroup Results by Sector

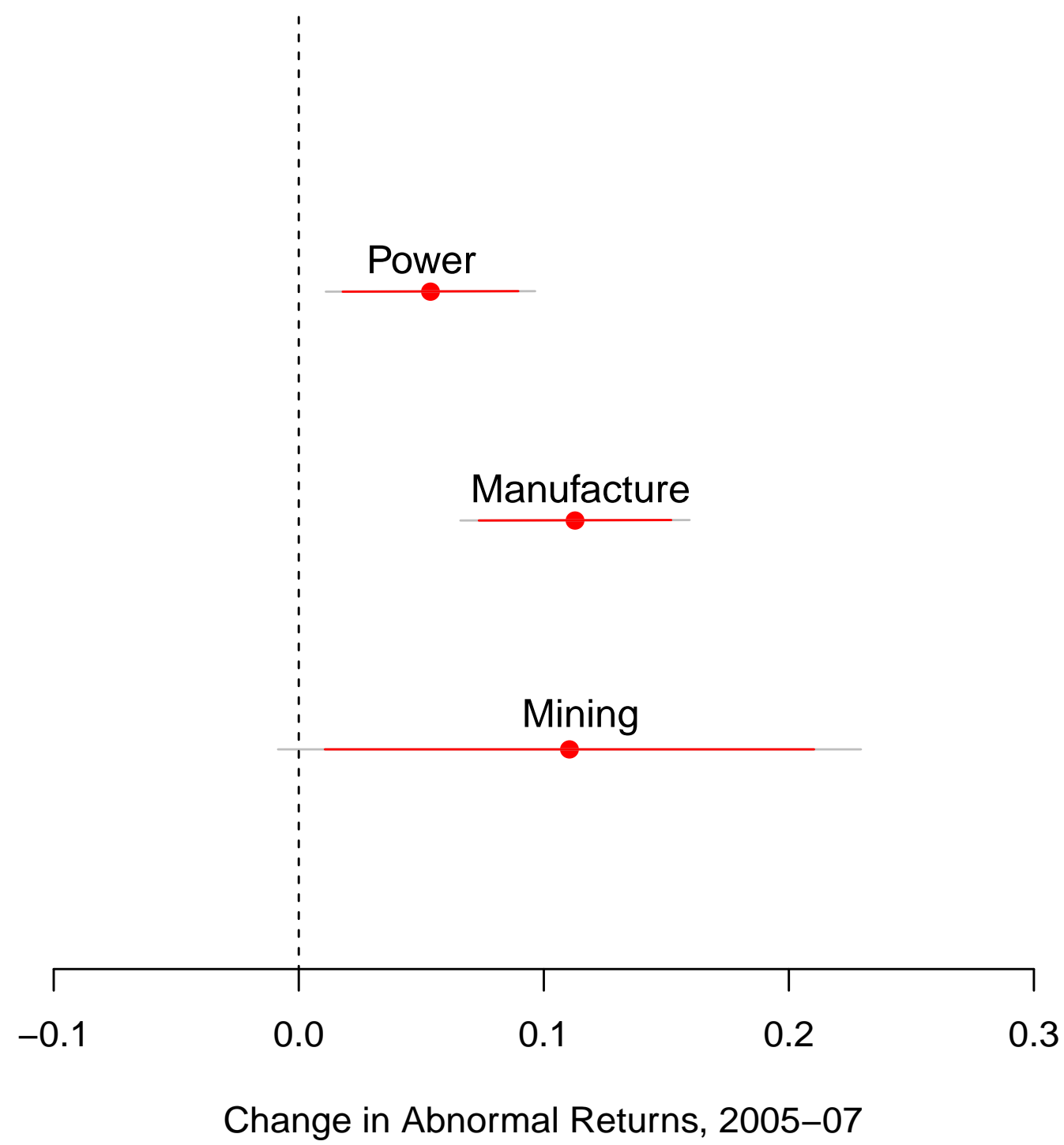

The figure illustrates the effect of Good UNFCCC Outcome as estimated in three fully specified linear fixed effects models based on three sector-based subsamples. These subsamples include power companies, manufacture companies, and mining companies, respectively. The outcome variable is the firms' Average Abnormal Returns. Each dot corresponds to the estimated coefficient, while the grey and coloured lines correspond to the $95 \%$ and $90 \%$ confidence intervals, respectively. 
Table A.6: The impact of UNFCCC decisions on the returns of EU ETS firms: Phase II, 2008-10

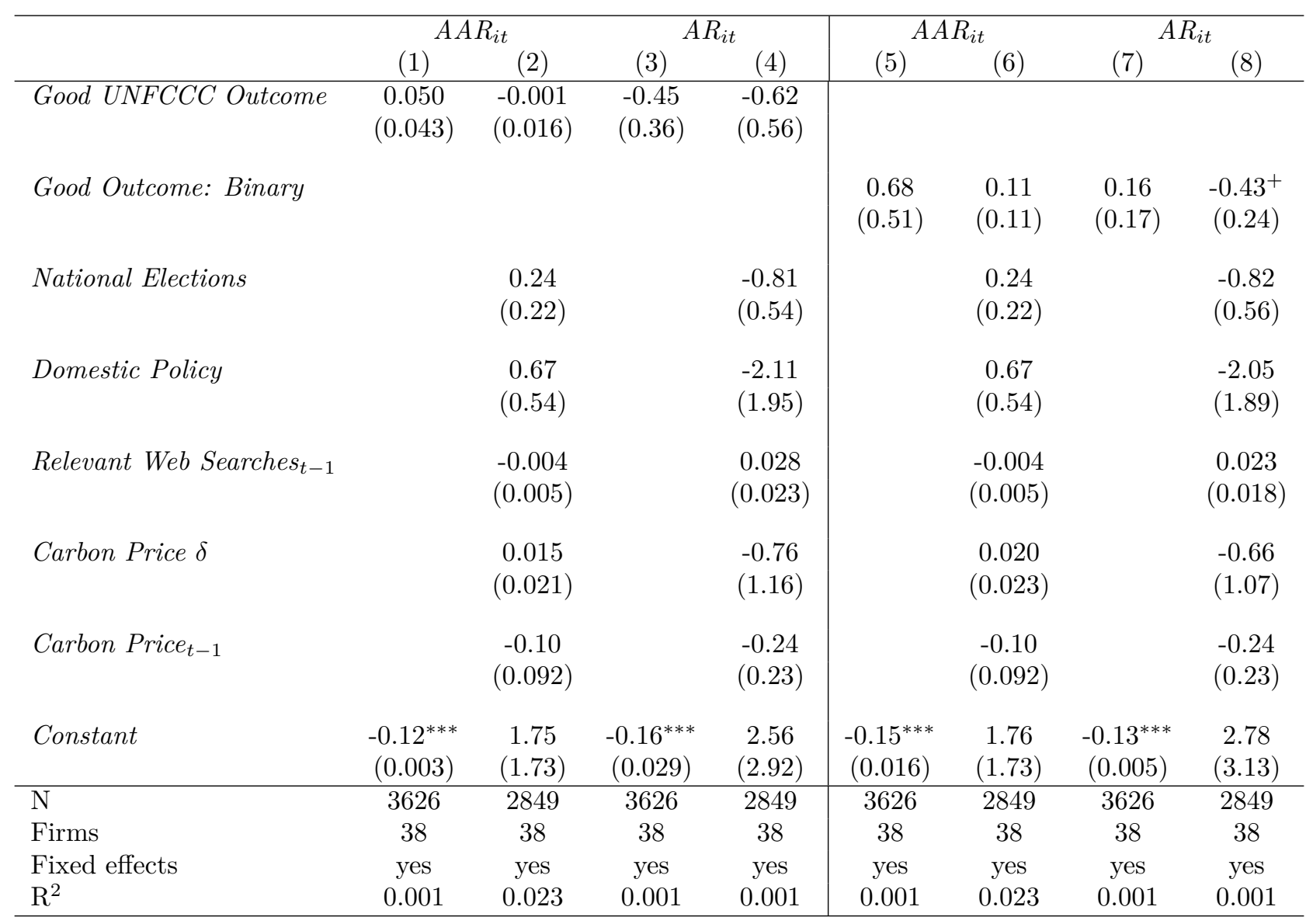

Linear coefficients. The outcome variable for Models 1-2 and 5-6 is $\mathrm{AAR}_{i t}$, while the outcome variable for Models 3-4 and 7-8 is $\mathrm{AR}_{i t}$. Firm, country and COP fixed effects estimated but not reported, while Relevant Web Searches $\delta$ is omitted because of collinearity. $+p<.1,{ }^{*} p<.05,{ }^{* *} p<.01,{ }^{* * *} p<.001$. 
Table A.7: The impact of UNFCCC decisions on the returns of EU ETS firms, 2005-07: Excluding UK Companies

\begin{tabular}{lcccc}
\hline & \multicolumn{2}{c}{$2005-07$} & \multicolumn{2}{c}{$2008-2010$} \\
& $\mathrm{AAR}_{i t}$ & $\mathrm{AR}_{i t}$ & $\mathrm{AAR}_{i t}$ & $\mathrm{AR}_{i t}$ \\
\hline Good UNFCCC Outcome & $0.10^{* * *}$ & $0.26^{*}$ & 0.006 & -0.91 \\
& $(0.025)$ & $(0.11)$ & $(0.024)$ & $(0.80)$ \\
National Elections & $0.12^{* * *}$ & -0.11 & 0.36 & -0.92 \\
& $(0.028)$ & $(0.081)$ & $(0.31)$ & $(0.78)$ \\
& & & & \\
Domestic Policy & $0.13^{* *}$ & $0.70^{+}$ & 0.95 & -3.10 \\
& $(0.041)$ & $(0.37)$ & $(0.76)$ & $(2.77)$ \\
Relevant Web Searches $\delta$ & $0.005^{* * *}$ & $0.038^{+}$ & 0.000 & 0.000 \\
& $(0.001)$ & $(0.020)$ & $(0.000)$ & $(0.000)$ \\
Relevant Web Searches $t-1$ & $0.007^{* * *}$ & $0.024^{* *}$ & -0.001 & -0.041 \\
& $(0.002)$ & $(0.008)$ & $(0.007)$ & $(0.033)$ \\
Carbon Price $\delta$ & $0.035^{* *}$ & 0.099 & 0.032 & -1.11 \\
& $(0.010)$ & $(0.063)$ & $(0.030)$ & $(1.66)$ \\
Carbon Price ${ }_{t-1}$ & & & & \\
& $0.039^{* *}$ & $0.18^{*}$ & -0.15 & -0.35 \\
Constant & $(0.011)$ & $(0.077)$ & $(0.13)$ & $(0.33)$ \\
& & & & \\
N & $-1.14^{* * *}$ & $-4.22^{*}$ & 2.55 & 3.64 \\
Firms & $(0.28)$ & $(1.64)$ & $(2.46)$ & $(4.17)$ \\
Fixed effects & 783 & 702 & 2002 & 2002 \\
$\mathrm{R}^{2}$ & 27 & 27 & 26 & 26 \\
& yes & yes & yes & yes \\
& 0.21 & 0.043 & 0.033 & 0.002 \\
\hline
\end{tabular}

Linear coefficients. Robust standard errors in parentheses. Firm and COP fixed effects estimated but not reported. $+p<.1,{ }^{*} p<.05,{ }^{* *} p<.01,{ }^{* * *} p<.001$. 
Table A.8: The impact of UNFCCC decisions on the returns of EU ETS firms, 2005-07: Country Clustered Standard Errors

\begin{tabular}{lcccc}
\hline & \multicolumn{2}{c}{$2005-07$} & \multicolumn{2}{c}{$2008-2010$} \\
& $\mathrm{AAR}_{i t}$ & $\mathrm{AR}_{i t}$ & $\mathrm{AAR}_{i t}$ & $\mathrm{AR}_{i t}$ \\
\hline Good UNFCCC Outcome & $0.068^{*}$ & 0.17 & -0.001 & -0.62 \\
& $(0.019)$ & $(0.10)$ & $(0.016)$ & $(0.59)$ \\
National Elections & $0.076^{+}$ & $-0.14^{*}$ & 0.24 & -0.81 \\
& $(0.018)$ & $(0.055)$ & $(0.22)$ & $(0.59)$ \\
& & & & \\
Domestic Policy & 0.075 & 0.37 & 0.67 & -2.11 \\
& $(0.066)$ & $(0.28)$ & $(0.57)$ & $(2.04)$ \\
Relevant Web Searches $\delta$ & $0.003^{*}$ & 0.027 & 0.000 & 0.000 \\
& $(0.001)$ & $(0.017)$ & $(0.000)$ & $(0.000)$ \\
Relevant Web Searches $t-1$ & $0.005^{*}$ & $0.016^{+}$ & -0.004 & 0.028 \\
& $(0.001)$ & $(0.006)$ & $(0.005)$ & $(0.024)$ \\
Carbon Price $\delta$ & & & & \\
& $0.024^{+}$ & 0.056 & 0.015 & -0.76 \\
Carbon Price ${ }_{t-1}$ & $(0.011)$ & $(0.032)$ & $(0.024)$ & $(1.24)$ \\
& & & & \\
Constant & 0.026 & 0.11 & -0.10 & -0.24 \\
& $(0.013)$ & $(0.060)$ & $(0.096)$ & $(0.24)$ \\
& & & & \\
N Firms & $-0.77^{+}$ & -2.61 & 1.75 & 2.56 \\
Fixed effects & $(0.29)$ & $(1.26)$ & $(1.79)$ & $(3.04)$ \\
$\mathrm{R}^{2}$ & 1094 & 983 & 2849 & 2849 \\
\hline & 38 & 38 & 37 & 37 \\
& yes & yes & yes & yes \\
& 0.16 & 0.031 & 0.034 & 0.001 \\
\hline & & & &
\end{tabular}

Linear coefficients. Country clustered standard errors in parentheses. Firm and COP fixed effects estimated but not reported. $+p<.1,{ }^{*} p<.05,{ }^{* *} p<.01,{ }^{* * *} p<.001$. 
Table A.9: The impact of UNFCCC decisions on the returns of EU ETS firms: Sector Clustered Standard Errors

\begin{tabular}{lcccc}
\hline & \multicolumn{2}{c}{$2005-07$} & \multicolumn{2}{c}{$2008-2010$} \\
& $(1)$ & $(2)$ & $(3)$ & $(4)$ \\
\hline Good UNFCCC Outcome & $0.068^{*}$ & 0.17 & -0.001 & -0.62 \\
& $(0.019)$ & $(0.10)$ & $(0.014)$ & $(0.51)$ \\
National Elections & $0.076^{*}$ & $-0.14^{+}$ & 0.24 & -0.81 \\
& $(0.018)$ & $(0.055)$ & $(0.19)$ & $(0.60)$ \\
& & & & \\
Domestic Policy & 0.075 & 0.37 & 0.67 & -2.11 \\
& $(0.066)$ & $(0.28)$ & $(0.48)$ & $(1.89)$ \\
Relevant Web Searches $\delta$ & $0.003^{*}$ & 0.027 & 0.000 & 0.000 \\
& $(0.001)$ & $(0.017)$ & $(0.000)$ & $(0.000)$ \\
Relevant Web Searches $t-1$ & $0.005^{* * *}$ & $0.016^{+}$ & -0.004 & 0.028 \\
& $(0.001)$ & $(0.006)$ & $(0.005)$ & $(0.020)$ \\
Carbon Price $\delta$ & & & & \\
& $0.024^{+}$ & 0.056 & 0.015 & -0.76 \\
Carbon Price ${ }_{t-1}$ & $(0.011)$ & $(0.032)$ & $(0.020)$ & $(1.15)$ \\
& & & & \\
Constant & 0.026 & 0.11 & -0.10 & -0.24 \\
& $(0.013)$ & $(0.060)$ & $(0.081)$ & $(0.21)$ \\
& & & & \\
N & $-0.77^{+}$ & -2.61 & 1.75 & 2.56 \\
Firms & $(0.29)$ & $(1.26)$ & $(1.53)$ & $(2.72)$ \\
$\mathrm{R}^{2}$ & 1094 & 983 & 2849 & 2849 \\
& 38 & 38 & 37 & 37 \\
& yes & yes & yes & yes \\
& 0.16 & 0.031 & 0.023 & 0.001 \\
\hline
\end{tabular}

Linear coefficients. Standard errors clustered on sector in parentheses. Firm, country and COP fixed effects estimated but not reported. $+p<.1,{ }^{*} p<.05,{ }^{* *} p<.01,{ }^{* * *} p<.001$. 
Table A.10: The impact of UNFCCC decisions on the returns of EU ETS firms: Montreal (2005) and Nairobi (2006) COPs

\begin{tabular}{|c|c|c|c|c|}
\hline & \multicolumn{2}{|c|}{ Montreal COP } & \multicolumn{2}{|c|}{ Nairobi COP } \\
\hline & (1) & (2) & (3) & (4) \\
\hline Good UNFCCC Outcome & $\begin{array}{l}0.14^{* *} \\
(0.040)\end{array}$ & $\begin{array}{l}0.10^{* *} \\
(0.030)\end{array}$ & $\begin{array}{l}0.093^{* *} \\
(0.027)\end{array}$ & $\begin{array}{l}0.038^{* *} \\
(0.011)\end{array}$ \\
\hline National Elections & & $\begin{array}{l}0.052^{* *} \\
(0.016)\end{array}$ & & $\begin{array}{l}0.11^{* *} \\
(0.032)\end{array}$ \\
\hline Domestic Policy & & $\begin{array}{l}0.29^{* * *} \\
(0.069)\end{array}$ & & $\begin{array}{l}-0.11^{* *} \\
(0.031)\end{array}$ \\
\hline Relevant Web Searches $\delta$ & & $\begin{array}{c}-0.009^{* * *} \\
(0.0025)\end{array}$ & & $\begin{array}{l}0.002^{* *} \\
(0.000)\end{array}$ \\
\hline Relevant Web Searches $s_{t-1}$ & & $\begin{array}{c}-0.017^{* * *} \\
(0.004)\end{array}$ & & $\begin{array}{l}0.003^{* *} \\
(0.000)\end{array}$ \\
\hline Carbon Price $\delta$ & & $\begin{array}{c}0.049^{* * *} \\
(0.013)\end{array}$ & & $\begin{array}{c}-0.016^{* *} \\
(0.004)\end{array}$ \\
\hline${\text { Carbon } \text { Price }_{t-1}}$ & & $\begin{array}{c}0.056^{* * *} \\
(0.014)\end{array}$ & & $\begin{array}{c}-0.020^{* *} \\
(0.005)\end{array}$ \\
\hline Constant & $\begin{array}{c}-0.074^{* * *} \\
(0.0042)\end{array}$ & $\begin{array}{c}-0.59^{* * *} \\
(0.13)\end{array}$ & $\begin{array}{l}-0.11^{* * *} \\
(0.0050)\end{array}$ & $\begin{array}{c}0.073 \\
(0.053)\end{array}$ \\
\hline $\mathrm{N}$ & 1050 & 676 & 1026 & 760 \\
\hline Firms & 38 & 38 & 38 & 38 \\
\hline Fixed effects & yes & yes & yes & yes \\
\hline $\mathrm{R}^{2}$ & 0.030 & 0.24 & 0.052 & 0.24 \\
\hline
\end{tabular}

Linear coefficients. The outcome for Models 1 and 2 is the AAR calculated for the Montreal COP days, while the outcome for Models 3 and 4 is the AAR the Nairobi COP days. Firm, country and COP fixed effects estimated but not reported. $+p<.1,{ }^{*} p<.05,{ }^{* *} p<.01,{ }^{* * *} p<.001$. 
Table A.11: Sampled non-EU ETS companies
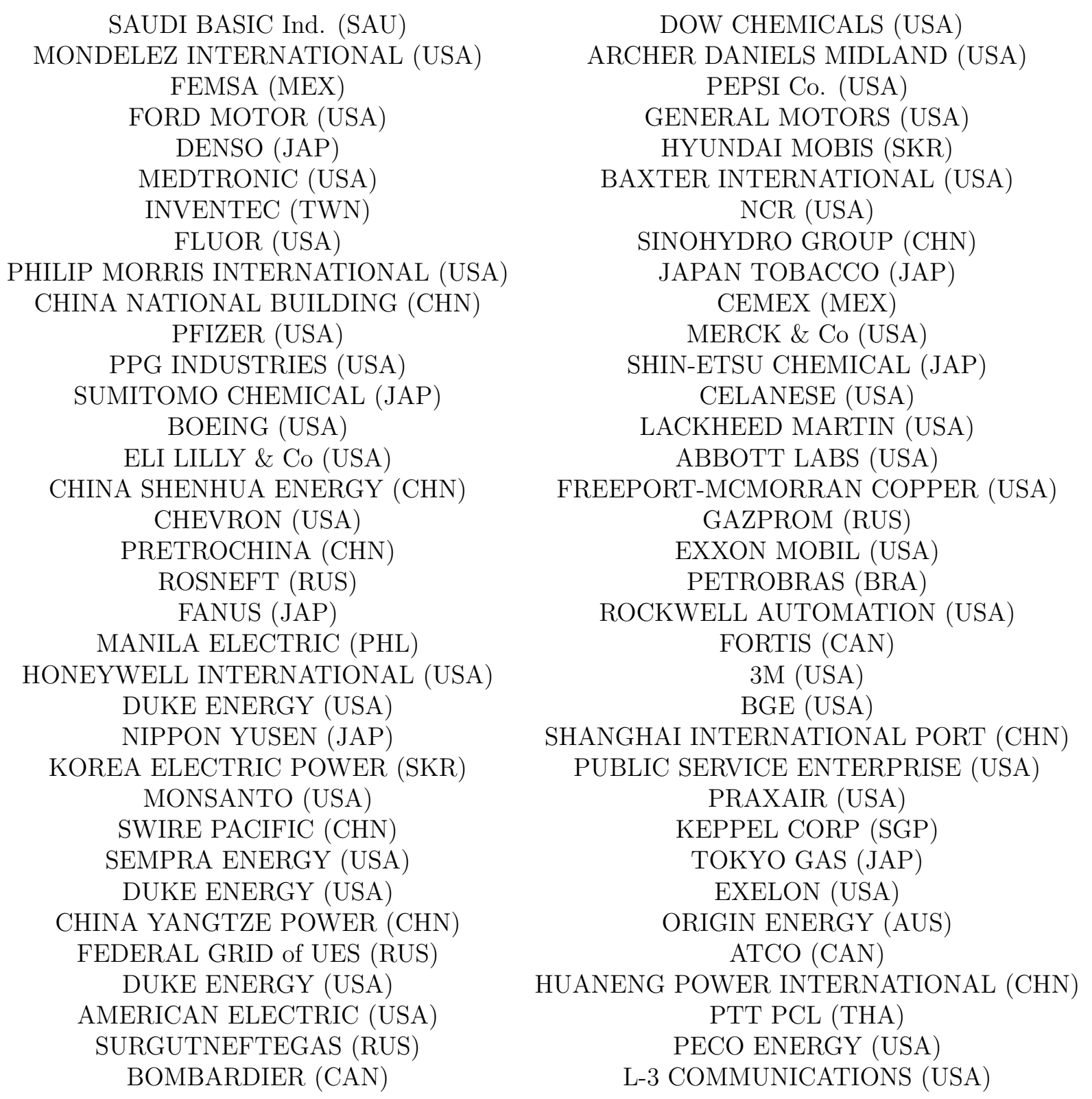

The table lists the non-European firms that have matching market characteristics to the $38 \mathrm{EU}$ according to the 2010 Forbes Global 2000 dataset. See main text for more details. 
Figure A.3: Non-EU Firms' Average Returns and Prices, 2005-2007
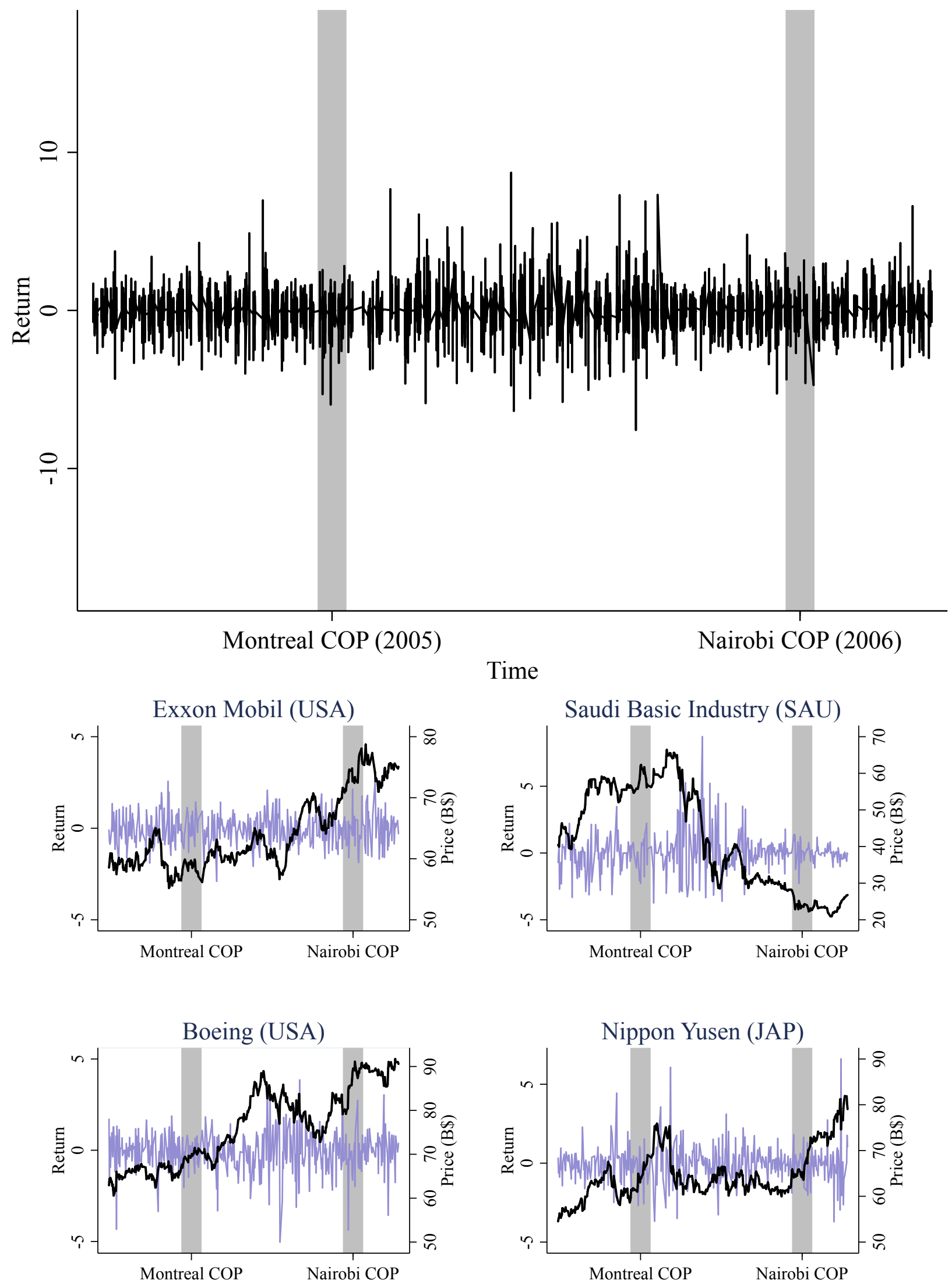

The top plot shows the average stock return of the 58 selected non-EU ETS (non-European) firms. The bottom plots show the return and price series for a selection of these firms. 
Table A.12: The Impact of UNFCCC decisions on non-EU firms' returns, 2005-07

\begin{tabular}{|c|c|c|c|c|}
\hline & \multicolumn{2}{|c|}{$A A R_{\text {it }}$ Models } & \multicolumn{2}{|c|}{$A R_{i t}$ Models } \\
\hline & $(1)$ & $(2)$ & $(3)$ & (4) \\
\hline Good UNFCCC Outcome & $\begin{array}{c}-0.037^{*} \\
(0.014)\end{array}$ & $\begin{array}{c}-0.034^{* *} \\
(0.011)\end{array}$ & $\begin{array}{c}0.031 \\
(0.040)\end{array}$ & $\begin{array}{c}0.038 \\
(0.039)\end{array}$ \\
\hline National Elections & & $\begin{array}{c}-0.068^{* *} \\
(0.021)\end{array}$ & & $\begin{array}{l}0.062^{+} \\
(0.033)\end{array}$ \\
\hline Relevant Web Searches $\delta$ & & $\begin{array}{c}-0.001^{*} \\
(0.001)\end{array}$ & & $\begin{array}{c}0.007 \\
(0.005)\end{array}$ \\
\hline Relevant Web Searches ${ }_{t-1}$ & & $\begin{array}{l}-0.001 \\
(0.001)\end{array}$ & & $\begin{array}{l}-0.001 \\
(0.002)\end{array}$ \\
\hline Carbon Price $\delta$ & & $\begin{array}{l}-0.006 \\
(0.005)\end{array}$ & & $\begin{array}{l}-0.001 \\
(0.033)\end{array}$ \\
\hline Carbon Price $_{t-1}$ & & $\begin{array}{c}-0.009^{*} \\
(0.004)\end{array}$ & & $\begin{array}{c}-0.048^{* *} \\
(0.018)\end{array}$ \\
\hline Constant & $\begin{array}{c}0.014^{* * *} \\
(0.0026)\end{array}$ & $\begin{array}{c}-0.028 \\
(0.080)\end{array}$ & $\begin{array}{c}0.013^{*} \\
(0.0056)\end{array}$ & $\begin{array}{c}0.37 \\
(0.41)\end{array}$ \\
\hline $\mathrm{N}$ & 2394 & 1656 & 2058 & 1488 \\
\hline Firms & 58 & 58 & 58 & 58 \\
\hline Fixed effects & yes & yes & yes & yes \\
\hline $\mathrm{R}^{2}$ & 0.008 & 0.004 & 0.001 & 0.004 \\
\hline
\end{tabular}

Linear coefficients. Robust standard errors in parentheses. The outcome variable for Models 1 and 2 is $\mathrm{AAR}_{i t}$, while the outcome variable for Models 3 and 4 is $\mathrm{AR}_{i t}$. Firm, country and COP fixed effects estimated but not reported. $+p<.1,{ }^{*} p<.05,{ }^{* *} p<.01,{ }^{* * *} p<.001$. 
Table A.13: The Impact of UNFCCC decisions on non-EU firms' returns, 2005-07 - Only Annex I countries

\begin{tabular}{|c|c|c|c|c|}
\hline & \multicolumn{2}{|c|}{$A A R_{i t}$ Models } & \multicolumn{2}{|c|}{$A R_{i t}$ Models } \\
\hline & (1) & (2) & (3) & (4) \\
\hline Good UNFCCC Outcome & $\begin{array}{c}-0.050^{* *} \\
(0.010)\end{array}$ & $\begin{array}{c}-0.043^{* * *} \\
(0.006)\end{array}$ & $\begin{array}{c}0.059 \\
(0.054)\end{array}$ & $\begin{array}{c}0.045 \\
(0.054)\end{array}$ \\
\hline National Elections & & $\begin{array}{c}-0.057^{*} \\
(0.031)\end{array}$ & & $\begin{array}{l}0.047^{+} \\
(0.024)\end{array}$ \\
\hline Relevant Web Searches $\delta$ & & $\begin{array}{c}-0.002^{* * *} \\
(0.001)\end{array}$ & & $\begin{array}{l}0.003^{*} \\
(0.002)\end{array}$ \\
\hline Relevant Web Searches $t_{t-1}$ & & $\begin{array}{c}-0.002^{* * *} \\
(0.000)\end{array}$ & & $\begin{array}{c}0.001 \\
(0.001)\end{array}$ \\
\hline Carbon Price $\delta$ & & $\begin{array}{l}-0.007 \\
(0.006)\end{array}$ & & $\begin{array}{c}0.009^{* *} \\
(0.036)\end{array}$ \\
\hline${\text { Carbon } \text { Price }_{t-1}}$ & & $\begin{array}{c}-0.011^{*} \\
(0.006)\end{array}$ & & $\begin{array}{l}0.002^{*} \\
(0.001)\end{array}$ \\
\hline Constant & $\begin{array}{c}0.019^{* * *} \\
(0.002)\end{array}$ & $\begin{array}{l}0.33^{* *} \\
(0.10)\end{array}$ & $\begin{array}{c}-0.010^{* * *} \\
(0.001)\end{array}$ & $\begin{array}{c}0.00 \\
(0.00)\end{array}$ \\
\hline $\mathrm{N}$ & 1862 & 1287 & 14028 & 10579 \\
\hline Firms & 45 & 45 & 45 & 45 \\
\hline Fixed effects & yes & yes & yes & yes \\
\hline
\end{tabular}

Linear coefficients. Robust standard errors in parentheses. The outcome variable for Models 1 and 2 is $\mathrm{AAR}_{i t}$, while the outcome variable for Models 3 and 4 is $\mathrm{AR}_{i t}$. Firm, country and COP fixed effects estimated but not reported. $+p<.1,{ }^{*} p<.05,{ }^{* *} p<.01,{ }^{* * *} p<.001$. 
Table A.14: Emission Trading Opinions among Firms: Additional Estimations

\begin{tabular}{|c|c|c|c|}
\hline & $\begin{array}{l}\text { Y: } \mathrm{CDM} / J I \text { projects will eliminate need } \\
\text { for internal abatement in EU ETS } \\
\quad \text { (Survey year: 2007) }\end{array}$ & $\begin{array}{r}(2) \\
Y: C D M / J I \text { is the } \\
\text { way to redu } \\
\text { (Survey year: 2007) }\end{array}$ & $\begin{array}{l}\text { (S3) } \\
\text { most cost-efficient } \\
\text { e emissions } \\
\text { (Survey year: 2013) }\end{array}$ \\
\hline EU ETS regulated & $\begin{array}{c}0.77 \\
(0.90)\end{array}$ & $\begin{array}{c}0.53^{* *} \\
(0.09)\end{array}$ & $\begin{array}{l}1.90^{*} \\
(0.88)\end{array}$ \\
\hline Emission: $0.1-0.5 \mathrm{Mt}$ & $\begin{array}{c}-1.71^{* * *} \\
(0.60)\end{array}$ & $\begin{array}{c}0.21 \\
(0.31)\end{array}$ & \\
\hline Emission: $0.5-1.0 \mathrm{Mt}$ & $\begin{array}{l}-0.55 \\
(0.43)\end{array}$ & $\begin{array}{c}-0.091 \\
(0.29)\end{array}$ & $\begin{array}{l}-0.81 \\
(0.63)\end{array}$ \\
\hline Emission: $1.0-5.0 \mathrm{Mt}$ & $\begin{array}{c}-1.57^{* * *} \\
(0.26)\end{array}$ & $\begin{array}{l}-0.18 \\
(0.61)\end{array}$ & $\begin{array}{c}1.24 \\
(1.04)\end{array}$ \\
\hline Emission: $5.0-10.0 \mathrm{Mt}$ & $\begin{array}{c}-1.35^{* * *} \\
(0.30)\end{array}$ & $\begin{array}{c}0.10 \\
(0.36)\end{array}$ & $\begin{array}{c}-1.53^{* *} \\
(0.53)\end{array}$ \\
\hline Emission: $>10 \mathrm{Mt}$ & $\begin{array}{c}-1.28^{* * *} \\
(0.24)\end{array}$ & $\begin{array}{c}0.29 \\
(0.25)\end{array}$ & $\begin{array}{l}0.086 \\
(0.54)\end{array}$ \\
\hline EUA access & $\begin{array}{c}0.47 \\
(0.83)\end{array}$ & $\begin{array}{c}0.11 \\
(0.21)\end{array}$ & \\
\hline Constant & $\begin{array}{c}-0.67^{* * *} \\
(0.26)\end{array}$ & $\begin{array}{c}2.59^{* * *} \\
(0.20)\end{array}$ & $\begin{array}{c}1.63 \\
(0.81)\end{array}$ \\
\hline Sector dummies & yes & yes & yes \\
\hline Country dummies & yes & yes & yes \\
\hline $\begin{array}{l}\mathrm{N} \\
\text { Log-likelihood }\end{array}$ & $\begin{array}{c}230 \\
-117.2\end{array}$ & $\begin{array}{c}231 \\
-347.8\end{array}$ & $\begin{array}{c}40 \\
-29.8\end{array}$ \\
\hline
\end{tabular}

The table reports additional regression results based on the Point Carbon data at the firm level. The first model reports coefficients from a probit model ( $\mathrm{Y}$ is binary 1 'yes' or 0 'no'), while the second and third models report coefficients from a linear model ( $\mathrm{Y}$ is scaled from 1 'completely disagree' to 5 'completely agree'). EUA Access is a binary variable that capture whether a firm was allocated EUAs; however, it is omitted in the third model because the question was not asked in the 2013 survey. The reference category for the Emissions variable is ' 0 ' for 2007 year, while it is '0 - 0.5 Mt' for the 2013 year. Standard errors are clustered at the sector level (note that sector categories in the surveys changed slightly between 2007 and 2013$) .{ }^{*} p<.1,{ }^{* *} p<.05,{ }^{* * *} p<.01$. 